I N T ER N ATIONAL MONETARY FUND

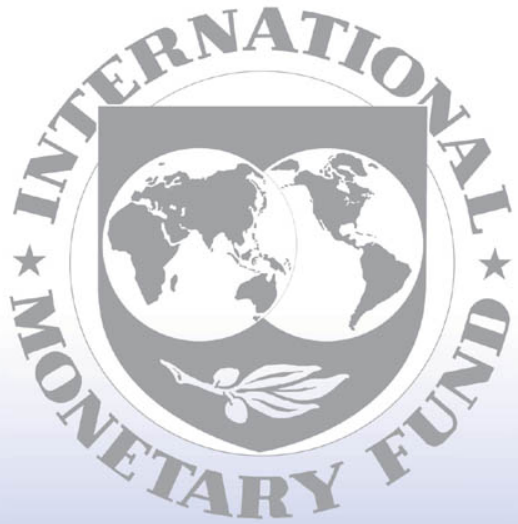

Staff

Country

Reports 


\section{Republic of Belarus: Ex Post Evaluation of Exceptional Access Under the 2009 Stand-By Arrangement}

This paper was prepared based on the information available at the time it was completed on December 14, 2010. The views expressed in this document are those of the staff team and do not necessarily reflect the views of the government of the Republic of Belarus or the Executive Board of the IMF.

The policy of publication of staff reports and other documents by the IMF allows for the deletion of market-sensitive information.

Copies of this report are available to the public from

International Monetary Fund • Publication Services

700 19th Street, N.W. • Washington, D.C. 20431

Telephone: (202) 623-7430 • Telefax: (202) 623-7201

E-mail: publications@imf.org • Internet: http://www.imf.org

\section{International Monetary Fund Washington, D.C.}




\section{INTERNATIONAL MONETARY FUND}

\section{REPUBLIC OF BELARUS}

\section{Ex Post Evaluation of Exceptional Access under the 2009 Stand-By Arrangement}

Prepared by an Interdepartmental Staff Team ${ }^{1}$

Authorized for Distribution by the European and Strategy, Policy and Review Departments

December 14, 2010

Contents

I. Introduction

II. Backdrop to the 2009 Program .$\underline{5}$

III. Evaluation of the Response .7

A. Was the Macroeconomic Response Appropriate? ……...................................... 1

B. Was the Approach to Structural Reforms Sufficiently Ambitious?....................... 18

C. Was the Fund's Financing Strategy Appropriate? ..........................................

D. Exceptional Access Procedures ....................................................................22

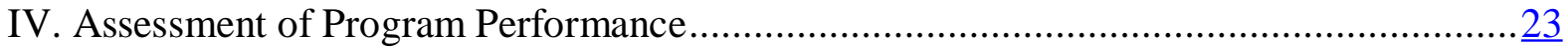

Annex

Belarusian Authorities' Comments to EPE Report

Table

Selected Economic Indicators, 2007-10 .$\underline{29}$

Figures

1. Program Projections and Outcomes .27

2. Comparison of Macroeconomic Performance with Other Program Countries $\underline{28}$

Boxes

1. Lending Under Government Programs .12

2. Choice of Exchange Rate Regime. 14

3. How did the Program Deal with Risks .$\underline{25}$

\footnotetext{
${ }^{1}$ The team comprised Donal McGettigan (head) and Mali Chivakul (both SPR), Shuang Ding (EUR), Lorenzo Forni (FAD), and Erik Lundback (MCM).
} 


\section{EXECUTIVE SUMMARY}

Belarus was hit hard by the global economic crisis. Although economic performance in the lead up to the crisis was generally strong, reforms lagged, and the crisis exposed Belarus's long-standing vulnerabilities, including its precariously low reserve levels.

An exceptional access Stand-by Arrangement (SBA) was, therefore, agreed in early 2009. The program aimed at addressing Belarus's most pressing vulnerabilities by agreeing large upfront financing, strong macroeconomic policy adjustment (devaluation, new exchange rate regime, and tight fiscal policy), and focused structural reforms. The program was seen as setting the stage for further reforms over the medium term under a successor program.

The program was generally successful and most program conditions met. As a result, the run on the rubel was stopped, deep recession was avoided, and unemployment kept low.

The program was overall well-designed, but with some shortcomings. Large upfront financing accompanied by a devaluation and a new exchange rate regime, tight fiscal policy and focused structural reforms were appropriate. But the need to change tack often on lending under government programs (LGP) and the exchange rate - due largely to unexpected shocks - meant that substantive program changes were needed on an ongoing basis. That said, the program took place in very uncertain times.

While in part due to external shocks, those problems experienced under the program also reflected rapid directed lending. Falling oil refining margins, lower gas import subsidies from Russia, and collapsing partner demand and sharp cross currency movements all hurt Belarus's economic performance (some of which might have been factored better into the initial program). And, because of program design issues (mainly on LGP) and the lack of a firm commitment by the authorities to rein in directed lending, LGP continued largely unabated during the program, leading to currency overvaluation and higher imports.

Looking ahead, the structural reform agenda remains largely unfinished. Given its short duration and crisis focus, the program correctly targeted on the most pressing structural reforms, mainly in the financial sector. While some of these were addressed, key identified reforms - notably on directed lending and privatization — were missed or delayed.

And macroeconomic vulnerabilities remain in the wake of the program. For example, Belarus's external debt burden has increased sharply (albeit from low levels), reserves remain low, and prospects of future financing difficulties cannot be ruled out.

While lessons from the review are many, the main one is the criticality of incorporating fully ownership, including at the highest levels, in program design and conditionality. This was particularly important for a case such as Belarus, where the 2009 program was, in effect, a rapid learning process after 15 years or so of mostly remote relations between Belarus and the Fund. The program fell far short on directed lending, an area where full ownership was missing. The same held, albeit to a lesser extent, on the need for a larger 
initial devaluation. While micromanagement is always a danger, and assessing ownership at the program outset is very difficult, it is at least debatable whether these problems could have been addressed through greater recognition of ownership issues, through the most senior levels, and different program design in these areas (for example, through greater reliance on prior actions or more explicit high-level endorsement of the program's goals). 


\section{INTRODUCTION}

1. The global economic crisis hit Belarus hard, prompting the authorities to request a Fund-supported program. Although economic performance in the years prior to the crisis was generally strong, underlying vulnerabilities, including an overvalued currency, large external current account deficits, dependence on Russia energy subsidies, and precariously low reserve levels were exposed by the global turmoil. In the wake of a precipitous loss of reserves, negotiations began on a Fund-supported program.

\section{The resulting SBA, approved in January 2009, helped Belarus navigate the} recent global economic crisis. The program aimed to facilitate an orderly adjustment to external shocks and to address pressing vulnerabilities. The program helped Belarus avoid a full-blown balance of payments crisis, avoid deep recession and preserve low unemployment under difficult circumstances.

3. Macroeconomic policy adjustment and external financing, together with focused structural reforms, helped secure this outcome. Under the program, Belarus used tight fiscal policy, wage restraint, and exchange rate adjustment, alongside focused structural reforms (mainly in the financial sector and privatization) to adjust during the crisis. The international community supported these efforts with exceptionally large financing, predominantly through the Fund.

\section{Belarus's efforts were also reflected in an uninterrupted program performance.}

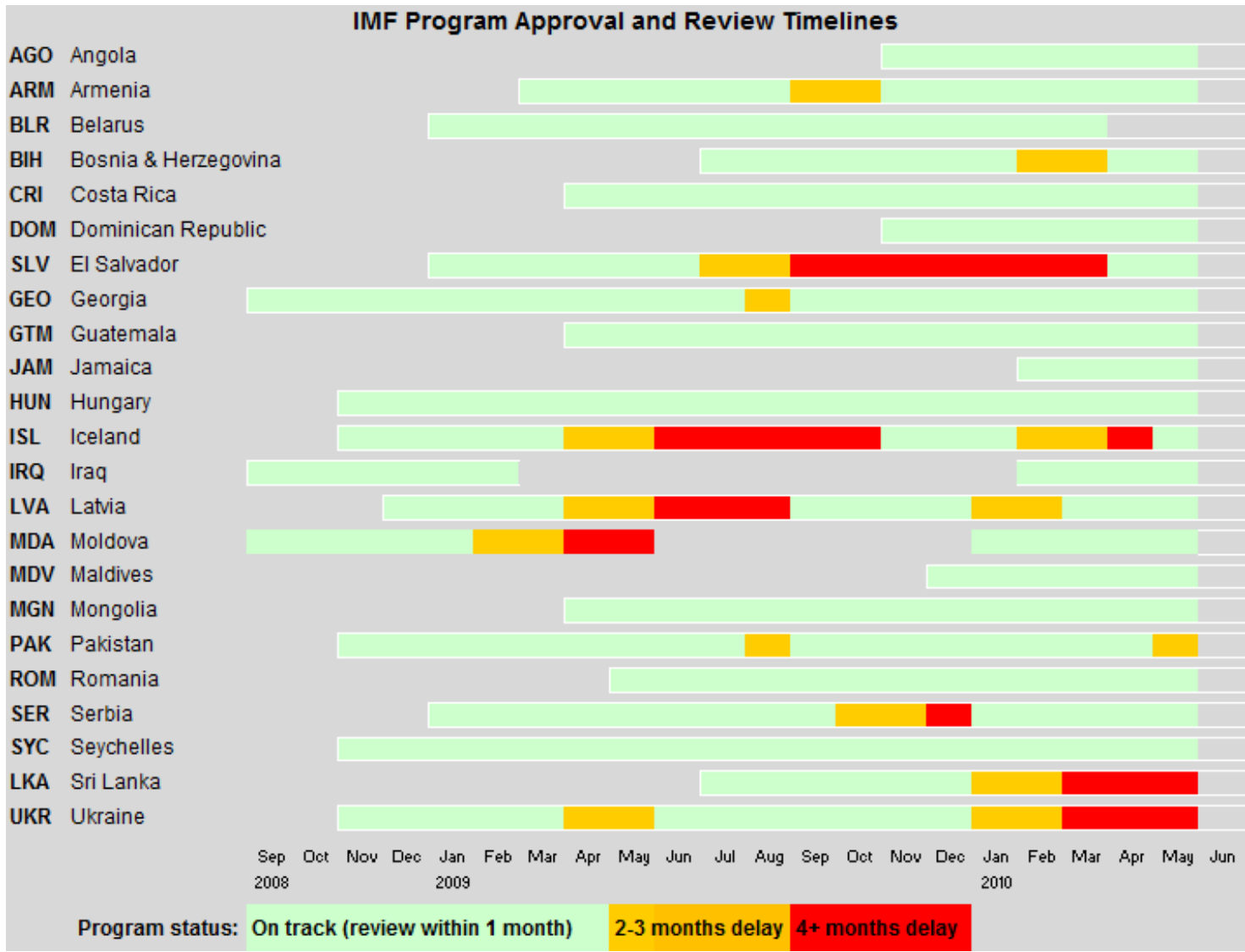


5. That said, in the wake of the program, vulnerabilities remain. The current account deficit rose to 13 percent of GDP in 2009- one of the few crisis programs to see the current account widen - and the external debt burden nearly doubled (albeit from a low base) in just over a year. And, despite the move to greater exchange rate flexibility, Fund staff estimates for the 2010 Article IV consultation suggest that the REER has become overvalued by about 14-16 percent. These shortcomings were due to external shocks and the continued strong credit growth, which fueled imports. Structural reforms also continue to lag. While many program measures were implemented, as discussed below, key targets-notably on directed lending and privatization-were missed or delayed.

6. Against this backdrop, the report assesses the effectiveness of the SBA, given the requirement for an evaluation in exceptional access cases. ${ }^{2}$ It focuses on two questions: (i) were the macroeconomic strategy, program design and financing appropriate and consistent with Fund policies, and (ii) did outcomes meet program objectives.

\section{BACKDROP TO THE 2009 PROGRAM}

7. Although Belarus lagged on reforms, economic growth was strong in the years leading up to the global crisis. Belarus's EBRD transition scores were low and FDI flows weak. Nevertheless, GDP growth averaged 8 percent over 2000-08, and foreign and public debt ratios remain among the lowest in the region, with social indicators among the highest. This reflects both pre-existing strengths (Belarus was an advanced Soviet republic), chosen policies (high investment), and a favorable external environment until the crisis (strong partner country growth and subsidized energy imports).

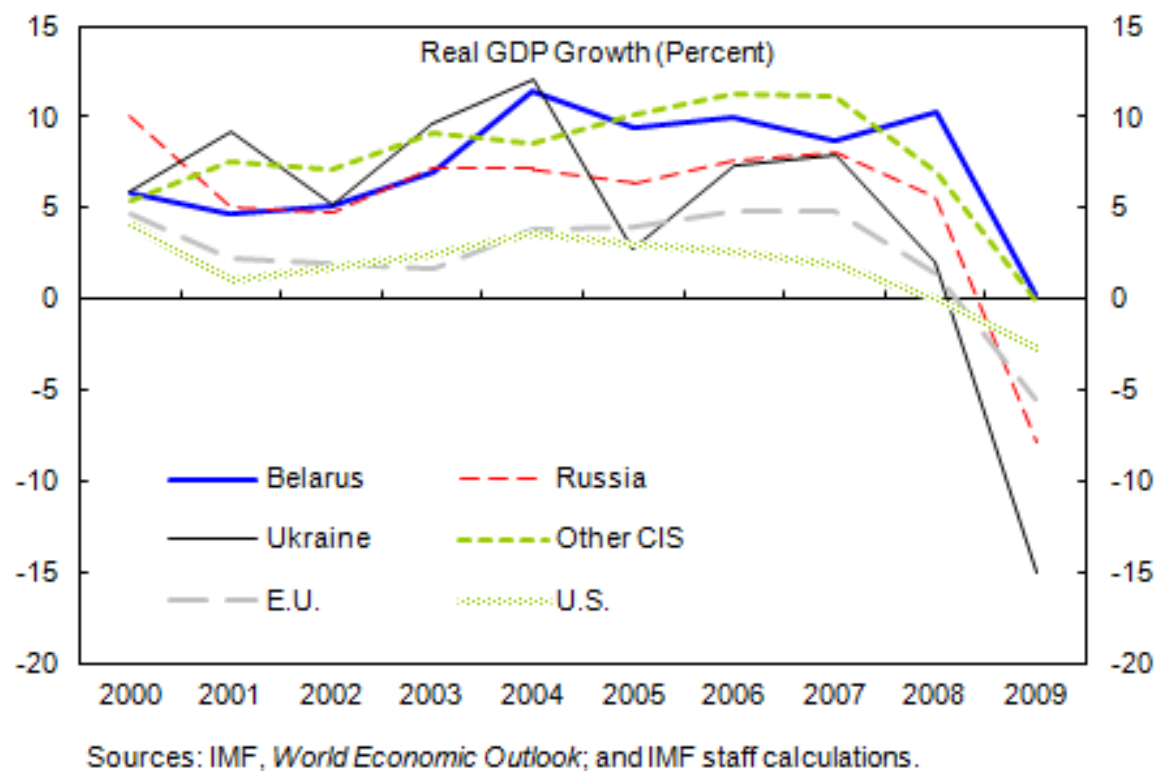

\footnotetext{
${ }^{2}$ See Ex Post Evaluations of Exceptional Access Arrangements_-Revised Guidance Note
} 
8. During the upswing underlying vulnerabilities were left largely unaddressed. As mentioned, structural reforms lagged. On the external side, wide current account deficits saw reserves dwindle: at end-2007, under a dollar peg, reserves amounted to only 11/4 months of imports and just over 50 percent of short-term debt. Moreover, geographic (CIS) and product (petroleum distillate) export bases remained narrow, and exposure to sudden changes in Russian energy subsidies was another key vulnerability. On the financial side, credit and liquidity risks remained high, and a government-led credit boom only added to these risks.

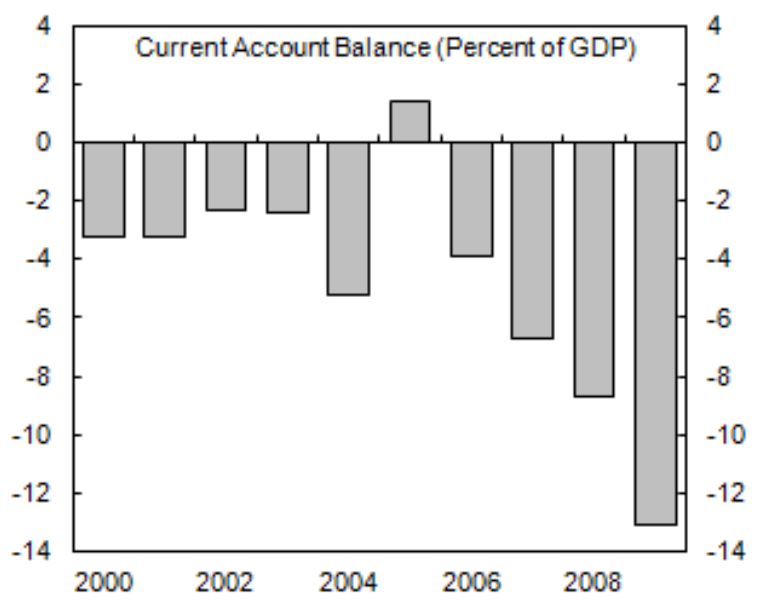

Sources: NBRB; and IMF staff calculations

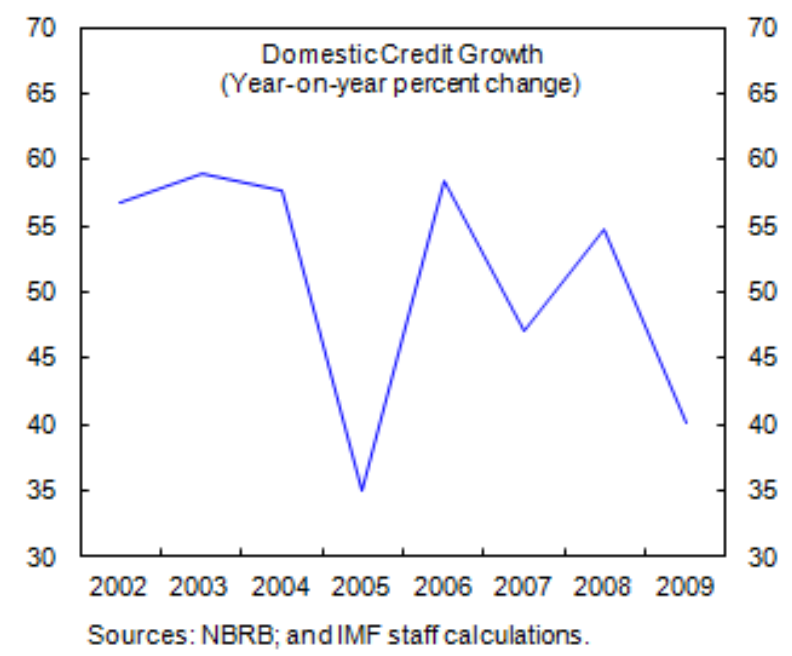

9. Policy relaxation just before the crisis aggravated the situation. The authorities relaxed policies in 2008 in the belief that Belarus would ride out the global crisis largely unscathed on the back of strong demand in the CIS region and high energy prices. This easing took the form of a large shift of budget deposits from the central bank to state-owned commercial banks to support rapid lending (up more than 50 percent in 2008). These policies in turn contributed to a sharp appreciation of the real effective exchange rate (REER), a marked widening of the external current account deficit, and higher inflation.

\section{The juxtaposition of vulnerabilities and external shocks led to a program}

request. In late 2008, falling oil prices hurt Belarus profits from exporting refined products and its gas subsidy from Russia was set to be cut further. Collapsing partner country demand and the steep rise in the REER (as the Russian ruble fell sharply against the dollar) further undercut export receipts. And, on the financial side, international credit lines to domestic banks were frozen, trade credits slumped and already-weak FDI flows fell further. As a result, international reserves fell precipitously as the NBRB defended the peg - by almost a fifth, from already low levels, in September through the first half of October alone-with the authorities initiating formal program negotiations in mid-October. Subsequent heavy reserve losses provided the backdrop for the conclusion of program negotiations.

\section{In January 2009 the Fund approved a 15-month SBA (access of}

SDR 1,618 million, or 419 percent of quota). The program aimed at adjusting to the external shocks and addressing Belarus's most pressing vulnerabilities by focusing on the following: (i) large upfront financing from the Fund and others, to boost reserves and avoid excessive contraction, (ii) strong macroeconomic policy adjustment in the form of exchange rate 
realignment, wage restraint and demand management, to rein in external imbalances, (iii) a more robust exchange rate regime built around a new currency basket with wider bands to act as a shock absorber, and (iv) key structural reforms (financial sector, price liberalization, privatization), to reduce financial sector risks and promote transition. The program was seen as setting the stage for further reforms over the medium term, with a successor program being considered at the outset.

\section{EVALUATION OF THE RESPONSE}

\section{In light of the program's objectives, and to address the first EPE objective} (strategy assessment), this section seeks to address the following: (i) was the macroeconomic response appropriate, (ii) was the approach to structural reforms sufficiently ambitious, and (iii) was the Fund's financing strategy appropriate. This section also assesses the extent to which Exceptional Access procedures were followed.

\section{A. Was the Macroeconomic Response Appropriate?}

13. The policy mix - exchange rate realignment supported by tight macroeconomic policies-was designed to offset earlier policy relaxation and to address vulnerabilities. Devaluation and wage restraint were used to address competitiveness concerns. These policies were to be buttressed by tight macroeconomic policies - a zero headline deficit, higher interest rates, and deceleration of credit growth - to help contain import demand and the current account deficit. Tight fiscal policy was also in line with the authorities' conservative approach to the budget, reflected in the low general government debt level (about 11 per cent of GDP at end-2008). At the same time macroeconomic tightening was not too restrictive, aiming to limit downside growth risks from the crisis. The policy measures were front-loaded, with upfront exchange rate devaluation and re-pegging, presidential approval of a balanced budget and a more limited wage increase implemented prior to the approval of the program.

14. In the event, the current account outcome was far worse than envisaged, a key program deviation, due to severe external shocks and lax credit policy. The current account deficit widened from 83/4 percent of GDP in 2008 to 13 percent in 2009, instead of narrowing to $5 \frac{1}{2}$ percent envisaged in the program. This was in large part attributable to the deeper-than-expected global recession, which in turn hurt Belarus's terms of trade and demand from partner countries, Russia in particular (Belarus's exports to Russia fell by almost 40 percent in 2009). A sharp terms of trade shock only added to this problem (see chart below). In response, the rubel was allowed to depreciate by another 8 percent relative to the basket, within a widened band (see below), during the year following the step devaluation, offsetting most of the effects from unfavorable cross-currency movements. The government also decided not to increase wage for the budgetary sector in 2009. The general government balance (deficit of 0.7 percent of GDP) ended up being somewhat worse than originally envisaged, but was consistent with the balanced budget after automatic adjustors were applied. However, the authorities continued to support domestic demand through the credit channel. This resulted in overall credit growth that was far higher than envisaged under the program, exacerbating greatly external imbalances. 

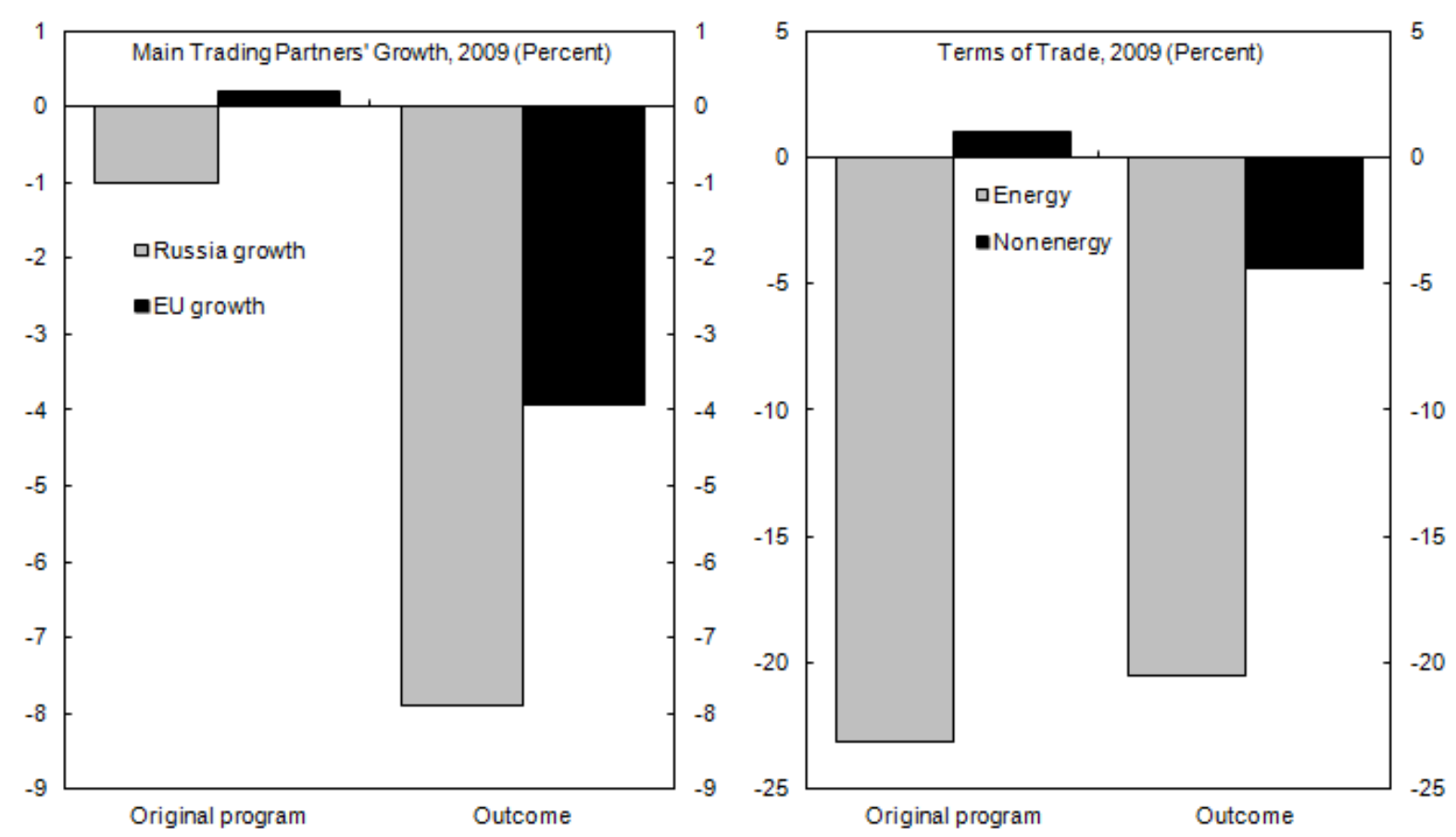

Source: IMF staff estimates and calculations.

\section{Fiscal policy}

15. Belarus's fiscal policy under the program was conservative, with a broadly balanced budget put in place despite major revenue losses. Although the general government primary balance moved from a surplus of 1.9 percent of GDP in 2008 to balance in 2009 , in cyclically adjusted terms it amounted to a contraction of about 1 percent of GDP (text table).

General Government Fiscal Position and Output Gap, 2006-11

(Percent of GDP, unless otherwise indicated)

\begin{tabular}{|c|c|c|c|c|c|c|}
\hline & 2006 & 2007 & 2008 & 2009 & 2010 & 2011 \\
\hline Revenue & 49.1 & 49.5 & 50.6 & 45.9 & 41.2 & 41.0 \\
\hline Primary expenditure & 47.3 & 48.6 & 48.7 & 45.8 & 42.8 & 42.5 \\
\hline Net interest expenditure & 0.4 & 0.4 & 0.6 & 0.8 & 1.0 & 1.1 \\
\hline Primary balance & 1.8 & 0.8 & 1.9 & 0.0 & -1.7 & -1.5 \\
\hline Overall balance & 1.4 & 0.4 & 1.3 & -0.7 & -2.7 & -2.6 \\
\hline $\begin{array}{l}\text { Real output gap (percent deviation from potential } \\
\text { real output) }\end{array}$ & 0.4 & 0.9 & 3.9 & -1.8 & -0.6 & 0.0 \\
\hline Cyclically-adjusted primary balance (CAPB) & 1.6 & 0.4 & 0.0 & 0.9 & -1.4 & -1.5 \\
\hline Fiscal impulse (change in CAPB) & -1.6 & 1.2 & 0.4 & -0.9 & 2.3 & 0.1 \\
\hline
\end{tabular}

Sources: Ministry of Finance; and IMF staff estimates and projections. 
16. Over the program period, external shocks and tax reforms led to severe revenue losses (from a high base). Export duties were hit badly as oil prices fell (loss of 3 percent of GDP). Along with falling profits, personal income, and VAT collections, overall revenue losses were estimated at about 51/2 percent of GDP at the time of the first review. At the same time the authorities implemented several tax reforms mainly to boost efficiency. In particular, several small taxes and fees were eliminated, including local sales taxes, with additional estimated revenue losses of 1 percent of GDP.

17. The program incorporated spending cuts of more than two percent of GDP and additional measures were taken to help offset revenue losses. Public investment was cut from high levels (yielding almost 2 percent of GDP in 2009 compared with original plans), wages were frozen $(0.2$ percent of GDP), subsidies and transfers rationalized $(0.5$ percent of GDP), VAT rates hiked by 2 percentage points (1 percent of GDP), fees for utilities and transportation increased, and goods and services spending rationalized (about 1 percent of GDP). At the same time, critical social spending programs were preserved.

\section{Lending under government programs}

18. By contrast, lending under government programs (LGP), a key quasi-fiscal activity, was not reined in successfully (Box 1).

-

Before the program concerns were
primarily about microeconomic
efficiency and financial stability. Large
directed lending had undermined bank
competition, crowded out normal
commercial credit, magnified sectoral
risk concentrations, reduced incentives
for banks (and borrowers) to manage
risks, and increased bank dependence on
public deposits.

- During the program, the macroeconomic consequences increasingly came into focus. In essence, large increases in LGP,

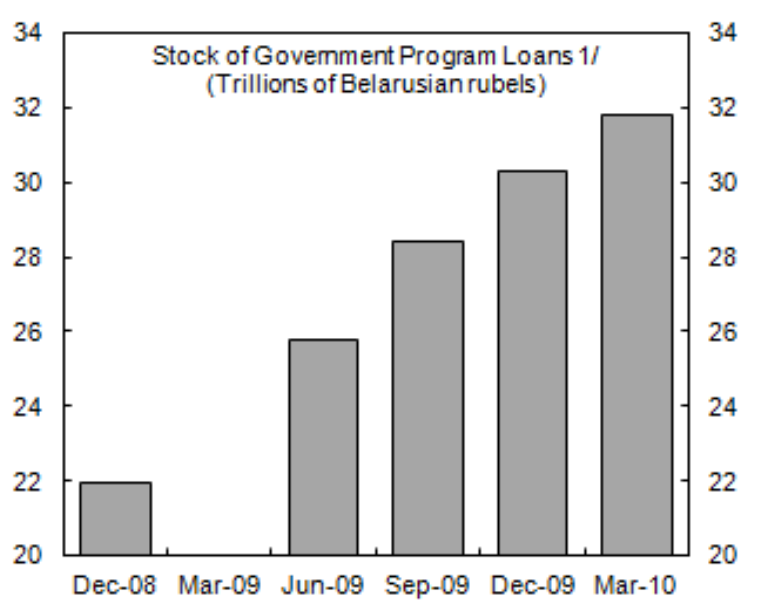

Sources: NBRB; and IMF staff estimates. $1 /$ For cpmparability, the December, 2008 number is an estimate based on revisions of data from June 2009 onwards. a critical quasi-fiscal activity in Belarus, undermined successful fiscal efforts elsewhere (see below). It became clear that LGP helped support demand in less productive sectors, contributing to widening external imbalances.

19. In response, measures to curb LGP were strengthened over the program period. At the outset of the program, it was believed that program measures would be effective. At the first review, the scale of the problem was not realized, partly reflecting lack of comprehensive data. As credit growth continued to grow rapidly, however, ever-tighter LGPrelated measures were agreed, with mixed results. 
LGP Program Coverage

\begin{tabular}{|c|c|c|c|}
\hline Timing & Financing of LGP & Direct Ceiling & $\begin{array}{l}\text { Other institutional framework } \\
\text { for LGP }\end{array}$ \\
\hline Outset & $\begin{array}{l}\text { Legislation preventing new } \\
\text { transfers to public deposit } \\
\text { accounts at commercial } \\
\text { banks enacted (prior action) } \\
\text { Existing deposits to be } \\
\text { transferred to NBRB as loans } \\
\text { repaid (prior action) }\end{array}$ & $\begin{array}{l}\text { New directed lending programs } \\
\text { financed with budget deposits } \\
\text { stopped (continuous structural } \\
\text { benchmark) }\end{array}$ & \\
\hline Second Review & $\begin{array}{l}\text { NBRB to stop all new lending } \\
\text { to banks at below-market } \\
\text { rates, except for housing } \\
\text { construction }\end{array}$ & $\begin{array}{l}\text { New government lending } \\
\text { programs prohibited in } 2009 \\
\text { (prior action) } \\
\text { Limit net lending under } \\
\text { government programs to } \\
3 \text { percent of GDP from June to } \\
\text { December } 2009\end{array}$ & \\
\hline Third Review & $\begin{array}{l}\text { No new liquidity support on } \\
\text { non-market terms and } \\
\text { outstanding stock limited to } \\
6 \text { percent of GDP (allowing } \\
\text { for already committed } \\
\text { disbursements). }\end{array}$ & $\begin{array}{l}\text { LGP tightened further, with } \\
\text { share in total claims expected } \\
\text { to fall from } 471 / 2 \text { percent at end- } \\
2009 \text { to } 46 \text { percent by end- } \\
2010 \text {, and to } 40 \text { percent by } \\
\text { end- } 2012\end{array}$ & $\begin{array}{l}\text { Decree setting up special financial } \\
\text { agency (SFA) to be submitted by } \\
\text { end-December } 2009 \text {. SFA to } \\
\text { distribute all new government } \\
\text { program loans by } 2011 . \\
\text { All new lending to be included } \\
\text { above the line in the budget }\end{array}$ \\
\hline Fourth Review & & $\begin{array}{l}\text { Limit on net LGP in } 2010 \\
\text { reduced further, reducing share } \\
\text { in total claims to } 43.5 \text { percent } \\
\text { by end- } 2010 \text {. } \\
\text { Council of Ministers resolution } \\
\text { asserting that agreed limits on } \\
\text { LGP are binding (prior action). }\end{array}$ & \\
\hline
\end{tabular}

20. Looking back, the original approach to curbing LGP was ineffective. The original prior action and structural benchmark, which were adhered to, aimed at limiting direct financing through government deposits, and not LGP itself. This was easily circumvented by sharply increased government deposits with the NBRB and then a dramatic increase in subsidized NBRB lending to banks, effectively channeling government deposits to the commercial banks. Hence, even though the authorities adhered to the letter of the program, the spirit was not met. It is, therefore, debatable the extent to which conditionality could have worked in the absence of full ownership, including at the highest levels, in this area. And, while overall NDA and NIR targets were met, save for end-March 2010, and the NIR target in the first review, LGP continued at a rapid pace in 2009, pointing to design problems (see below).

21. Subsequent measures were more effective, but LGP growth remained a problem. With a direct ceiling, the LGP increase slowed, although the increase in the second half of 2009 still exceeded the agreed limit. The ceiling for the first quarter of 2010 was tighter, but was not met. Measures to cap NBRB non-market lending seem to have been effective once a quantitative cap on the overall outstanding amount was introduced, although it appears the NBRB then began buying bank securities to meet banks financing needs. The likely impact 
of a Special Financing Agency (SFA) is unclear, but the implementation of an SFA framework has slowed after the fourth review.

\section{Going forward, what can be learned?}

- Ownership is critical. The authorities implemented a set of strong spending measures and managed to counteract severe revenue losses in very difficult circumstances. The contrast between this and LGP performance boils down to ownership, including at the highest levels. One possible way of addressing this is to secure explicit highest-level commitment to the overall program goals.

- $\quad$ On LGP, there seems to have been an initial underestimation by staff of the macroeconomic importance of LGP and the fact that it could be financed by sources other than government deposits. That said, the program was adapted as the extent of LGP growth and ineffectiveness of the measures became apparent, although this led to the program being continuously renegotiated.

- Given its importance, direct quantitative ceilings on LGP and NBRB non-market based lending to banks may have worked better, perhaps in the form of PCs. It is not obvious, however, that formal conditionality would have been fully effective given weak ownership. Lack of comprehensive data on LGP at the start of the program posed an additional challenge and one that perhaps could have been flagged at the outset (see Box 1).

- $\quad$ Consideration should be given to including net LGP in the fiscal accounts above the line. If the government wants to provide targeted sectors and companies with cheap credit this should be fully reflected in the budget and the fiscal outcome. 
Box 1. Lending Under Government Programs

Bank lending under government programs (LGP) plays a central role in Belarus. The programs are typically implemented through presidential decrees or resolutions of the Council of Ministers that recommend lending to particular projects, sectors, or companies.

Borrowers pay low interest rates, and banks are compensated through budget subsidies (see chart). In addition, many of the recommended credits carry central and local government guarantees (Box 1 in the 2009 FSAP Update).

Most LGP financing has come from government deposits and financing from the NBRB at favorable terms. The standard NBRB Lombard credit fixed interest rate was 20 percent or higher in 2009 , while financing from special decisions by the NBRB board typically carry much lower interest rates (about $91 / 2$ percent through August-2009). ${ }^{3}$

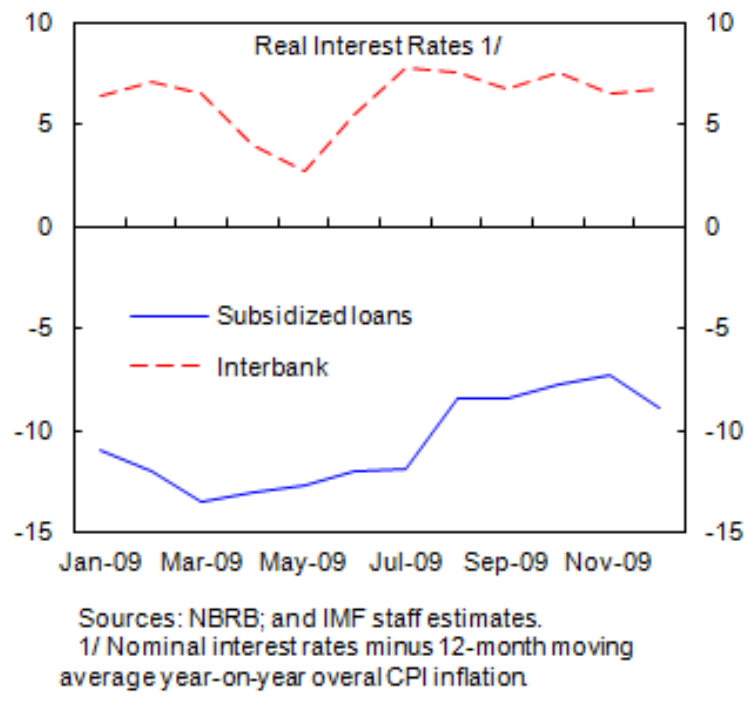

During the Fund-supported program LGP increased rapidly. The amount of outstanding LGP increased by almost 50 percent, at program exchange rate, from end-2008 to end-March 2010. The share of LGP in overall credit to economy rose from 45 percent to 48 percent, at program exchange rate, during the same period. Looking at flows, it can also be seen that LGP disbursements reached their highest level in 2009, following a steeply increasing trend since 2005. The bulk of this credit has been going to agriculture and construction (mostly residential).

The data on LGP are quite limited. Disbursements of loans are available since 2005, but stock data only start at end-2008. In addition, the short stock data series has a major break in mid-2009 when the NBRB started to compile data on LGP more comprehensively, leading to an upward revision of the end-June 2009 stock by about 29 percent.

\section{Monetary and exchange rate policy}

23. Before the recent crisis, the authorities pegged the rubel to the dollar. This peg helped the rubel act as a store of value and unit of account in the context of deep structural changes. From 2003 until the crisis, the peg anchor helped lower inflation from high to intermediate levels while growth remained strong.

\footnotetext{
${ }^{3}$ No more recent information is available.
} 

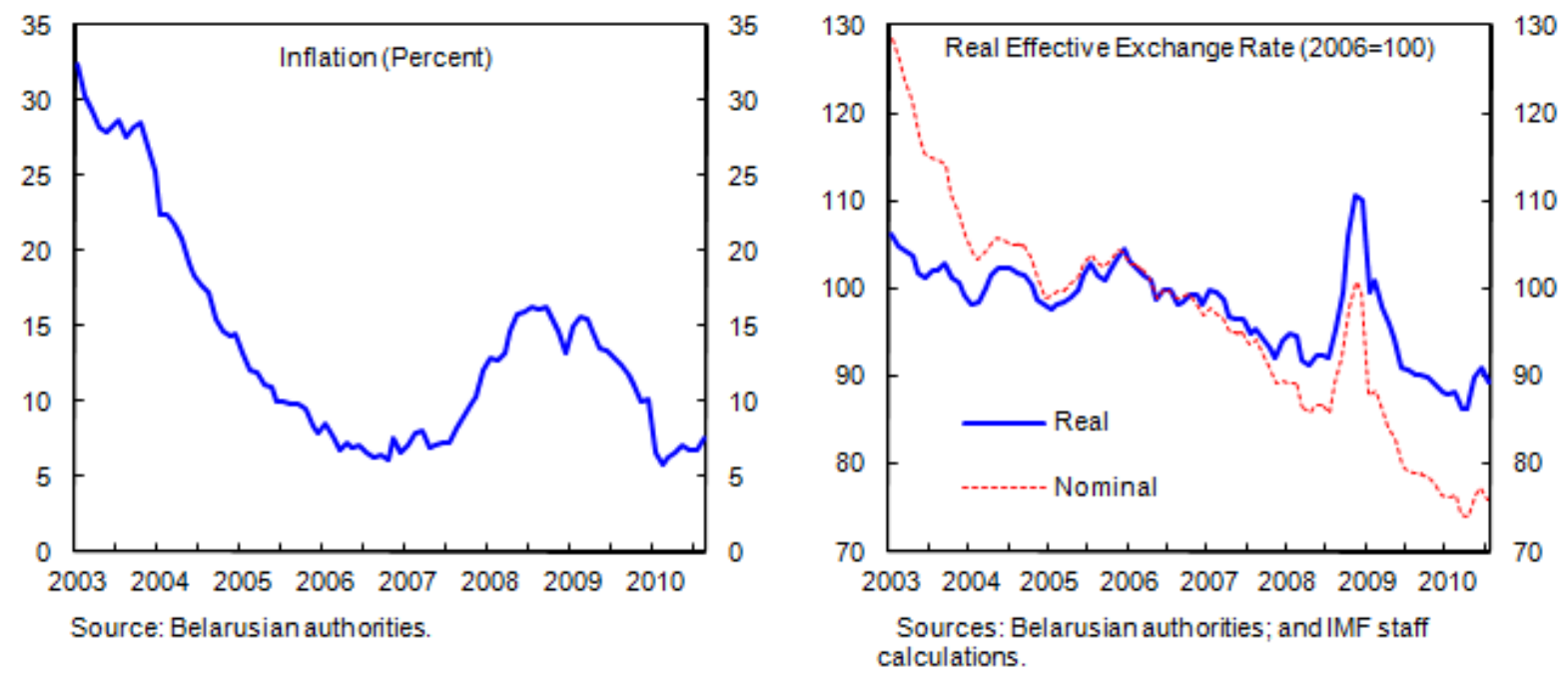

24. The crisis called for a change in exchange rate regime. With Russia as Belarus's largest trading partner, and the volume of financing transactions in Russian rubles and euros growing, Belarus's narrow peg to the dollar became increasingly problematic in 2008. The volatility of dollar-euro and dollar-ruble rates undermined inflation control on the dollar downside early in 2008 and created competitiveness problems on the dollar's late 2008 strength. Staff analysis suggested the rubel was likely overvalued just prior to the start of the program by about 11-14 percent. In the end, the authorities were forced off the dollar peg given the steep reserve losses in the run up to the crisis. 
Box 2. Choice of Exchange Rate Regime

At the outset of the program, two key questions presented themselves: how to move to a new exchange rate regime and what new regime to adopt?

On the first, the authorities could have engineered (i) a step devaluation, or (ii) a gradual depreciation. With clear and credible communication, a step devaluation, supported by appropriate interest rate policy, could limit capital outflows and dollarization that typically work through the expectation channel. By contrast, it is typically far more difficult to set expectations for the public in the case of a gradual depreciation. With an unclear anchor on the exchange rate level, a gradual depreciation can lead to a self-fulfilling run on the currency as the public loses faith in the currency. That said, a step devaluation could also lead to the same result if the policy is poorly communicated and the size of the devaluation is not seen as credible.

Any new exchange rate regime also needs to be credible and operational. It should be perceived as capable of withstanding shocks and providing an anchor to keep inflation in check. Exiting from a peg, Belarus had a number of exchange rate regimes to consider:

1. Re-peg with the US dollar at a weaker exchange rate level. To make the framework more flexible, a band could have been used to accommodate volatility. Although such an approach would be operationally easy as well as providing a clear and familiar anchor for the public, it would have remained vulnerable to cross-currency volatility, a key weakness manifested prior to the devaluation.

2. Basket peg with the relevant currencies (US dollar, euro and the Russian ruble). A peg to a basket of relevant currencies could be used to provide the necessary anchor and help alleviate the effects of the volatility of the trading partner currencies. To provide some flexibility to the framework, a band that is sufficiently wide to absorb the likely volatility could also be used.

3. A managed float. This option was not available to Belarus, since floating requires reasonably deep foreign exchange markets and Belarus, with its history of high inflation, needed an anchor at the start of the program. An alternative anchor, in the form of inflation targeting, would have required extensive preparation, clear public buy in, and a monetary transmission mechanism under which the interest rate plays a key role.

25. This took the form of a one-step devaluation and a peg to a currency basket, with program reserve floors to guide foreign exchange intervention.

- After difficult negotiations, a step devaluation of 20 percent against the dollar from the end-October 2008 level was agreed and implemented on January 2, 2009 as a prior action. This was designed to help correct the estimated misalignment (allowing for exchange rate pass-through), thus helping close the large 2009 external financing gap, while preserving an anchor.

- $\quad$ The new framework also included a simultaneous switch to a currency basket (equal weight on the euro, dollar, and Russian ruble, again a prior action), with the new anchor better reflecting the structure of Belarus's trade and financing flows. The widening of the band to \pm 5 percent helped the regime better absorb shocks. 
- Given the margins of error associated with valuation estimates, the program also built in a mechanism for additional adjustment, whereby the band would be widened and additional depreciation would take place within the band in the event of a failure to rein in the current account deficit or negative shocks.

- To guide decisions on foreign exchange intervention within the new band, the program put in place a floor on net international reserves (NIR) on the NBRB, specified to encourage reserve accumulation from low starting levels.

26. Was this strategy appropriate? We focus on the following questions: (i) how well did the chosen strategy work in terms of meeting the program's objective, and (ii) could alternative exchange rate strategies have worked better.

\section{How well did the chosen strategy work?}

- While achieving the real depreciation envisaged in the program, the strategy did not help as much as anticipated in reining in macroeconomic imbalances partly because of continued rapid LGP growth. In other program countries, adjustment came from a much stronger contraction of imports as domestic demand fell and, in some cases, the currency adjusted by more. In Belarus's case, the REER depreciated by 16 percent from October 2008 to early 2010, correcting the sharp appreciation right before the crisis, with the initial step devaluation bringing down the REER by about 8 percent (chart). However, rapid LGP expansion appears to have kept imports from falling further, a source of new misalignment. On the export side, the drop in external demand, in particular from Russia, and a worsening of the terms of trade (much worse than other program countries, Figure 2) outweighed any competitiveness gain from the devaluation.

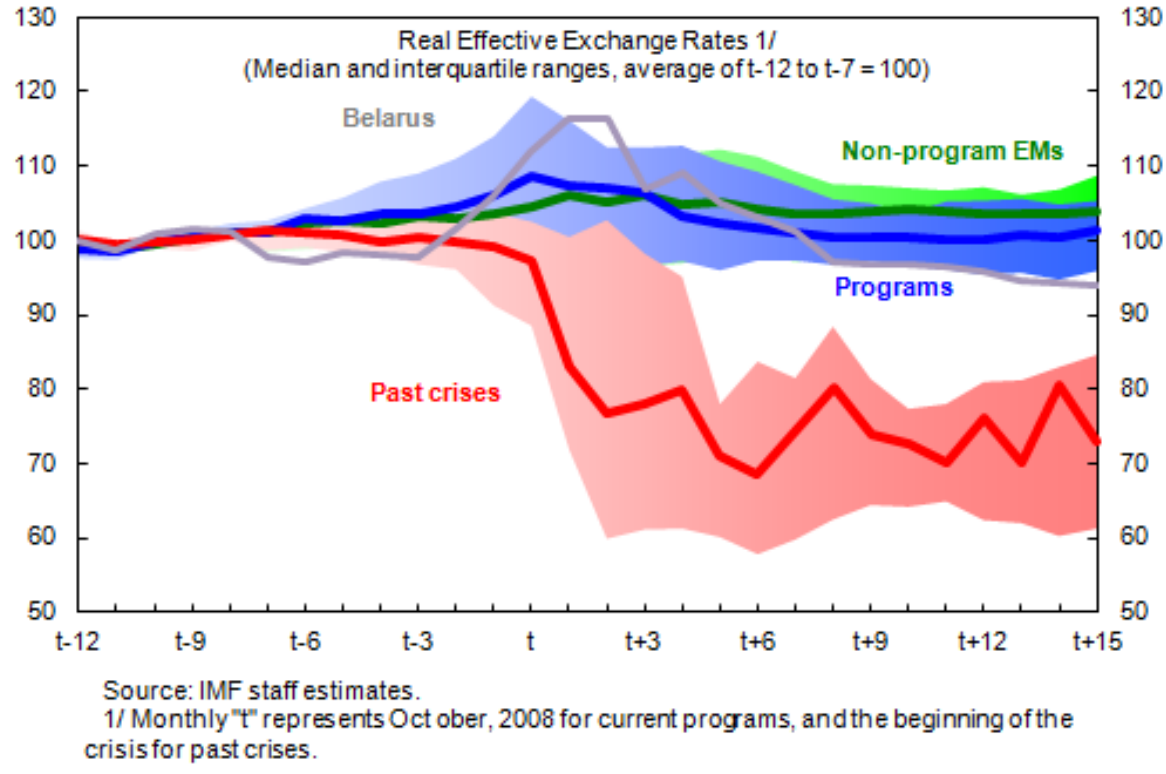


- $\quad$ External shocks also called for ongoing adjustment under the new regime. Faced with further ruble devaluation, a largerthan-expected contraction in Russia and the EU and terms-of-trade shocks, pressures remained on the currency as the current account deficit remained large and capital inflows unpredictable. A shortfall in official funding added to the financing gap. The band was, therefore, widened to \pm 10 percent in the first half of 2009 and re-centered at end-2009 following the movement of the rubel against the basket currencies.

- The course of action also contributed to an increase in dollarization. Initially, and without sufficiently clear communication, coupled with the authorities' attempt to maintain a stable rubel-dollar nominal rate, Belarus experienced an increase in dollarization of deposits through June 2009, jumping from 38 percent of the total to 49 percent. With the basket peg more established and the global financial market relatively more stable in the second half of 2009, pressure on the currency subsided and some deposit de-dollarization was observed.

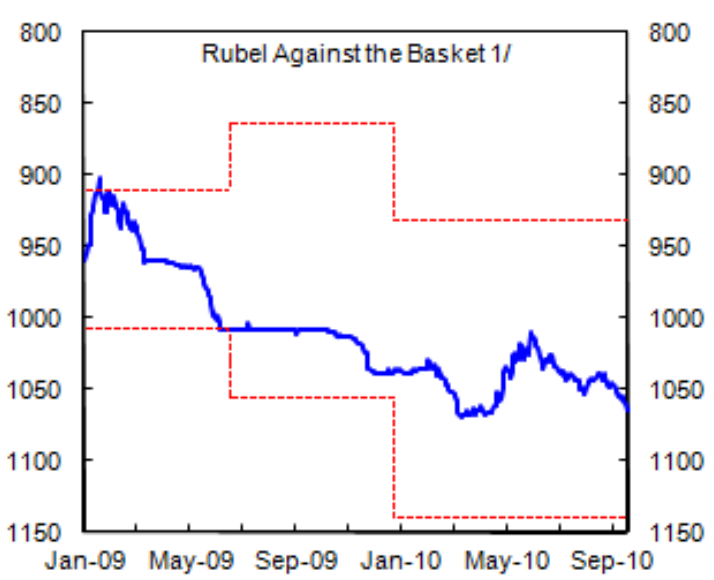

Source: National Bank of the Republic of Belarus. $1 /$ The basket rate is calculated using BCSE exchange rates.

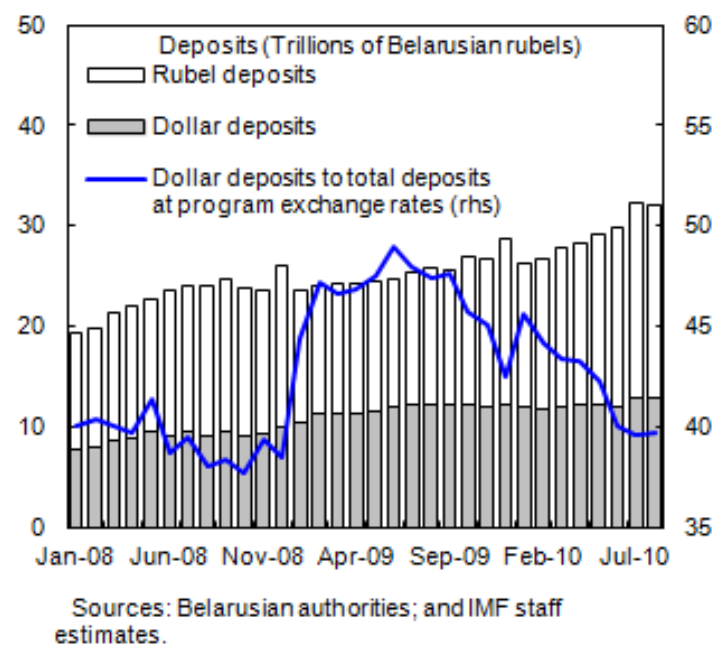

28. Moving to monetary policy, although it initially aimed at supporting the peg, it was later used instead to support the economy. The authorities increased refinancing interest rates by 4 percentage points in January 2009 and committed to raise interest rates further if needed to fight renewed outflows and support the peg. Refinancing rates were, however, brought down starting in November 2009 to support the economy. It became clear early in the program that rubel deposit interest rates were not increased enough to stem a run on the currency. Rubel interest rates were raised in the context of the first review (prior action) to increase the spread between rubel and foreign

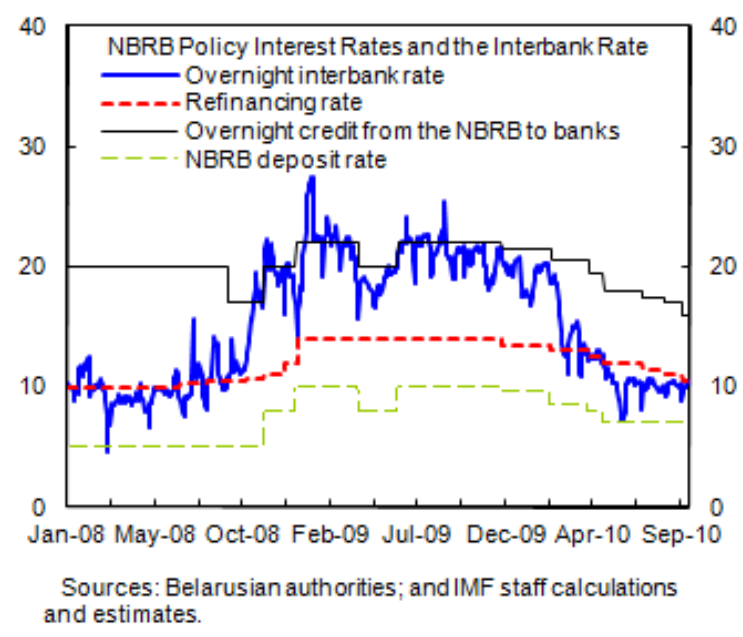


currency interest rates. Moreover, and importantly, the tightened monetary policy stance was not fully passed through to the real economy given large subsidized government lending programs.

\section{As for monetary targets, a higher money multiplier, deposit dollarization and non-conventional practices allowed Belarus to meet NDA targets even given higher} credit growth. Reflecting downward GDP growth revisions and faster disinflation over the course of 2009, the reserve money target in the original program was adjusted downwards during program reviews, although the outcomes turned out even lower than these revised targets. That said, broad money growth turned out to be higher than originally programmed, owing to a higherthan-expected rubel money multiplier and deposit dollarization. This allowed the banking system to substantially expand credit to the economy with a shrunken monetary base. NIR targets were also met in part because of some non-conventional actions on the part of the NBRB. This left room to meet the NDA

Financial Soundness Indicators, 2008-10

\begin{tabular}{|c|c|c|c|}
\hline & 2008 & 2009 & $\begin{array}{l}2010 \\
\text { Sep. }\end{array}$ \\
\hline \multicolumn{4}{|l|}{ Capital adequacy } \\
\hline Total regulatory capital to risk-weighted assets & 21.8 & 19.8 & 19.0 \\
\hline Tier I regulatory capital to risk-weighted assets & 16.9 & 14.4 & 13.9 \\
\hline Capital (net worth) to assets & 18.6 & 16.7 & 14.0 \\
\hline \multicolumn{4}{|l|}{ Asset composition } \\
\hline Loans to state-owned enterprises & 22.6 & 24.9 & 23.0 \\
\hline Foreign exchange loans to total loans & 30.9 & 29.6 & 26.4 \\
\hline \multicolumn{4}{|l|}{ Asset quality } \\
\hline Nonperforming loans to gross loans & 1.7 & 4.2 & 4.0 \\
\hline Provisions to total nonperforming loans & 70.0 & 44.9 & 55.7 \\
\hline \multicolumn{4}{|l|}{ Earnings and profitability } \\
\hline ROA (profits to period average assets) & 1.4 & 1.4 & 1.7 \\
\hline ROE (profits to period average equity) & 9.6 & 8.9 & 11.1 \\
\hline \multicolumn{4}{|l|}{ Liquidity } \\
\hline Liquid assets to total assets & 23.2 & 28.4 & 28.7 \\
\hline Loan to deposit ratio & 170.8 & 189.2 & 207.5 \\
\hline Customer deposits to total (non-interbank) loans $2 /$ & 58.5 & 51.5 & 48.5 \\
\hline Foreign exchange liabilities to total liabilities & 38.7 & 44.0 & 41.1 \\
\hline
\end{tabular}

Source: Belarusian authorities.

1/ Loans classified in categories III, IV and V.

2/ Customer deposits include bank accounts, demand and term deposits of individuals, legal entities, and nonbank financial institutions. Data as of June, 2010. targets as the latter is defined as the difference between reserve money and NIR. ${ }^{4}$

30. Rapid credit growth has left the banks vulnerable. Banks now rely on NBRB credits to extend loans, resulting in loan-to-deposit ratio almost doubling over the program period. NPLs have also been on the rise, but this is partly explained by new classification rules, and the deterioration of portfolio quality has not yet been dramatic. However, the negative effects from rapid credit growth tend come with a lag, and it is quite possible that some of the LGP has contributed to hide a weakening repayment capacity among borrowers. The rapid credit growth also put pressure on funding indicators during 2009 e.g., the loan to deposit ratio increased from 171 percent at end-2008 to 206 percent at end-June 2010.

\footnotetext{
${ }^{4}$ Actions included selling assets excluded from IMF-defined international reserves to increase official reserves, lengthening the maturity of foreign government deposits to just over one year so that they were not counted as foreign liabilities, and early termination of foreign exchange forward contracts, accompanied by a simultaneous spot purchase of foreign exchange by the NBRB just before test dates.
} 


\section{What are the possible lessons?}

- $\quad$ The choice of the basket peg was sound. It reflected better Belarus's trade patterns, yet was simple and transparent. And Belarus was not ready for a more flexible regime under an IT framework (Box 2).

- $\quad$ The size of the initial band was appropriate. Under pegs bands are typically narrow initially to aid credibility. Moving to a larger band at the start would have been risky as the public may not have been able to adapt quickly to greater uncertainty. As the public became comfortable with the new regime, the width of the band was increased.

- In contrast, a larger upfront devaluation, although difficult to secure (see bullet below), would have helped Belarus cope with the subsequent collapse of partner demand - a distinct possibility in the wake of the Lehman crisis — and the early Russian ruble devaluation. ${ }^{5}$ The absence of private sector balance sheet constraintsan advantage over many other emerging markets - would have allowed this without major costs. Larger upfront adjustment could have limited the need for band modifications later in 2009.

- Here again, program ownership is critical. The authorities had a strong preference for adjustment by means other than a large exchange rate devaluation. In particular the authorities were keen to preserve confidence in the exchange rate regime by avoiding an overly abrupt devaluation, a concern repeatedly emphasized by the authorities. The extent to which staff could prevail against these strong authority views is debatable.

- $\quad$ Clearer upfront communication could have helped limit the impact of near-term shocks and helped limit dollarization.

\section{B. Was the Approach to Structural Reforms Sufficiently Ambitious?}

32. In the lead up to the crisis structural reforms lagged in Belarus. Despite strong growth, state intervention in the economy was pervasive: price and wage controls; centrally planned macroeconomic and enterprise level targets; strong regulations; and state control of many enterprises. The state was also active in banking, most notably in the form of LGP and state ownership (market share of about 75 percent in the lead up to the program).

33. The structural agenda was quite focused, however. The program had 13 prior actions and benchmarks that can be characterized as structural, with eight on financial and monetary and the remainder addressing public sector involvement in the economy (text table). Non-benchmarked measures included: (i) tax reforms (halving the turnover tax, and

\footnotetext{
${ }^{5}$ As of mid-December, 2008, before the step devaluation decision was finalized, the NDF as well as the forward market indicated that the Russian ruble would depreciate by 10 percent against the US dollar within three months. These implied projections were, however, made at times of great uncertainty and turmoil.
} 
reducing local sales and personal income taxes); (ii) reducing price controls; and (iii) measures to strengthen depositor faith in banks and to formalize the institutional framework for dealing with financial crises.

34. This focus was appropriate. The program lasted for only 15 months, a short window for designing and implementing structural reforms. The program was, furthermore, agreed under time pressure at the height of the global financial crises. The focused structural policy agenda was also in line with the Fund's move to streamlined structural reforms. In terms of substance, financial and central bank reforms were of critical macroeconomic importance and within the Fund's core mandate. Likewise, real sector measures addressed fundamental economic issues such as price flexibility, state interference with production and employment decisions at firm level, privatization, and public sector wages.

\section{Close cooperation with the World Bank took place in the structural area. The} 2009 Bank Development Policy Loan had a broad structural policy agenda and in some areas the Fund and Bank programs overlapped (privatization, price flexibility, taxes) with close cooperation, and important technical expertise provided by the Bank. In other areas, the Bank program was an important complement to that of the Fund. In the financial and monetary areas the Fund took much of the lead, but there was important cooperation on the SFA.

36. Program implementation in the financial and monetary areas was strong, except on LGP. Interest rate ceilings on bank loans were eliminated, loan classification was brought in line with best international practice, the operational independence of the NBRB was increased (effective January 2011), and a large state bank was privatized. Outside conditionality, a MoU on crisis preparedness and management was signed by key public bodies.

37. Compliance in other areas was also generally strong. Benchmarks were introduced during the program to lay the legal groundwork for setting up a privatization authority (first review) and to compile a list companies to be privatized (third review). These benchmarks were satisfied, but privatization of large SOEs was disappointing (not helped by the difficult global situation). Progress was made on price liberalization, including dropping items subject to regulated prices and abolishing price registration for new products. Finally, tax reform advanced, even if the system remains unduly complex: several small taxes and fees, including local sales taxes were eliminated.

38. In hindsight, what lessons can we learn?

- Coordination with the Bank is critical. The Fund does not have the resources or expertise to address all important issues and cooperation with the Bank worked well and contributed to the overall success of the program.

- $\quad$ Ownership is key. The program was put in place after a prolonged period of somewhat remote relations between Belarus and the Fund. Once the program was put in place, while there was a genuine willingness to implement some policies (e.g. on banking), in other areas the authorities appeared less committed (e.g., on LGP). This mattered crucially for program performance regardless of conditionality. 
Belarus: Program Prior Actions and Structural Benchmarks

\begin{tabular}{|c|c|}
\hline Prior actions and structural benchmarks & Notes \\
\hline \multicolumn{2}{|l|}{ Financial and Monetary } \\
\hline $\begin{array}{l}\text { Eliminate additional deposit transfers from the central and local governments to commercial } \\
\text { banks. }\end{array}$ & $\begin{array}{l}\text { Prior action, original program. Met } \\
\text { (with minor deviations). }\end{array}$ \\
\hline $\begin{array}{l}\text { Abolish the interest rate ceiling for rubel lending to the corporate sector by the President adopting } \\
\text { an appropriate Resolution. }\end{array}$ & Prior action, original program. Met. \\
\hline $\begin{array}{l}\text { Engage a qualified, experienced, and reputable consultant, on a competitive basis, to assist in } \\
\text { preparing state-owned banks for partial or full privatization. }\end{array}$ & $\begin{array}{l}\text { Benchmark for end-August } 2009 . \\
\text { Partially met. }\end{array}$ \\
\hline $\begin{array}{l}\text { In line with FSAP recommendations, bring loan classification practices in line with best } \\
\text { international practices. }\end{array}$ & Benchmark, original program. Met. \\
\hline Refrain from approving any new directed lending programs financed with budget deposits. & $\begin{array}{l}\text { Continuous benchmark throughout } \\
\text { the program. Met. }\end{array}$ \\
\hline $\begin{array}{l}\text { Prepare draft amendments and supplements to the Statute of the NBRB with further } \\
\text { amendments being introduced into the Banking Code to ensure operational and financial } \\
\text { independence of the NBRB }\end{array}$ & Benchmark from $1^{\text {st }}$ review. Met \\
\hline $\begin{array}{l}\text { Decision of the Presidium of the Council of Ministers to suspend the adoption of new government } \\
\text { lending programs through end-2009. }\end{array}$ & Prior action, $2^{\text {nd }}$ review. Met. \\
\hline $\begin{array}{l}\text { Issue a Council of Ministers resolution asserting that the agreed limits on overall credit under } \\
\text { government programs are binding. }\end{array}$ & Prior action, $4^{\text {th }}$ review. Met. \\
\hline \multicolumn{2}{|l|}{ Real Sector } \\
\hline Limit the wage increase for budgetary workers in November 2008 to 5.3 percent. & Prior action, original program. Met. \\
\hline Eliminate the regulatory act imposing a general ceiling on monthly prices increases of $1 / 2$ percent. & $\begin{array}{l}\text { Benchmark throughout the } \\
\text { program. Met. }\end{array}$ \\
\hline Submit to the Head of State a draft Decree on establishing a Privatization Agency. & Benchmark from $1^{\text {st }}$ review. Met \\
\hline $\begin{array}{l}\text { Issue a Council of Ministers recommendation to line ministries and other government agencies in } \\
\text { charge of economic activity, including local governments, not to set any quantitative targets for } \\
2010 \text {, such as output and employment targets, for the companies that do not benefit from } \\
\text { government's financial support and in which the government has a minority share. }\end{array}$ & Benchmark from $2^{\text {nd }}$ review. Met \\
\hline $\begin{array}{l}\text { Compile a list of enterprises from the list of companies included in the privatization plan for } 2008- \\
10 \text { and task the privatization agency with preparing these enterprises for privatization through an } \\
\text { open, international, transparent and competitive bidding process }\end{array}$ & Benchmark from $3^{\text {rd }}$ review. Met. \\
\hline \multicolumn{2}{|l|}{ Continuous prohibitions on balance of payment transactions and exchange rate arrangements } \\
\hline Prohibition on the accumulation of external payments arrears. & Not violated. \\
\hline $\begin{array}{l}\text { Prohibition on the imposition or intensification of restrictions on the making of payments and } \\
\text { transfers for current international transactions. }\end{array}$ & Not violated. \\
\hline $\begin{array}{l}\text { Prohibition on the conclusion of bilateral payments agreements that are inconsistent with Article } \\
\text { VIII. }\end{array}$ & Not violated. \\
\hline Prohibition on the introduction or modification of multiple currency practices. & Not violated. \\
\hline $\begin{array}{l}\text { Prohibition on the imposition or intensification of import restrictions for balance of payments } \\
\text { reasons. }\end{array}$ & Not violated. \\
\hline
\end{tabular}




\section{Was the Fund's Financing Strategy Appropriate?}

39. Relative to its gross financing needs, Fund financing for Belarus was in line with other high access cases. ${ }^{6}$ Although the program was just 15 months in length, access was set at more than 400 percent of quota, accounting for almost a fifth of Belarus's gross financing need. However, given worse-than-expected external shocks, access was augmented to about 600 percent of quota at the first review (without extending the program, as a successor program was envisaged, although with the benefit of hindsight extension might have given more time for the authorities to achieve program objectives, thereby smoothing the transition to a new program). Following augmentation, gross Fund financing accounted for about 28 percent of Belarus's gross financing needs (text chart).

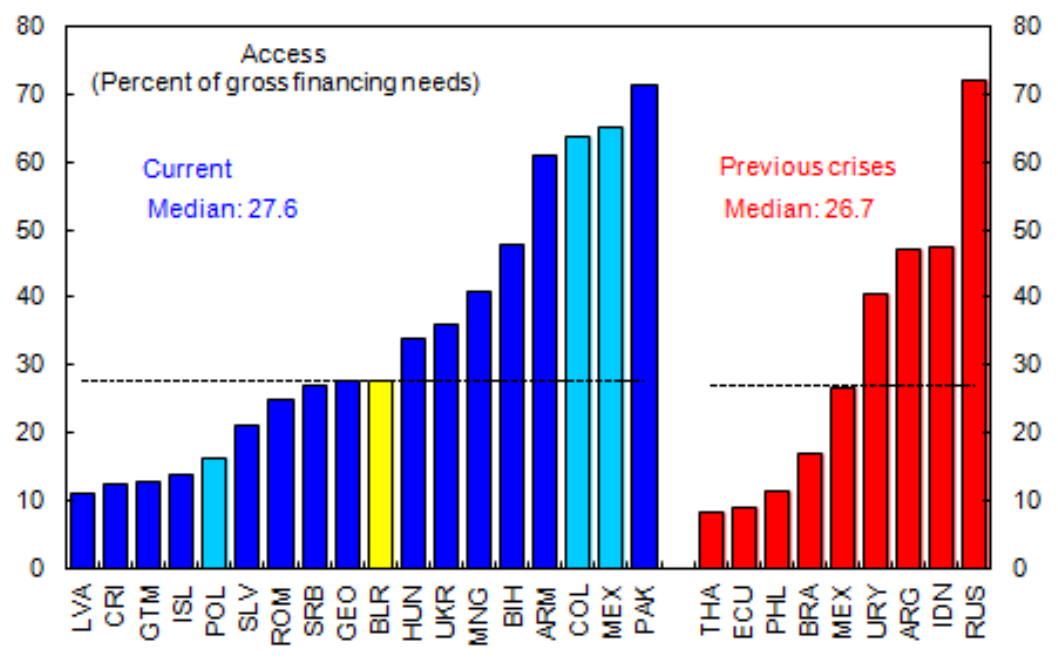

Source: IMF staff estimates.
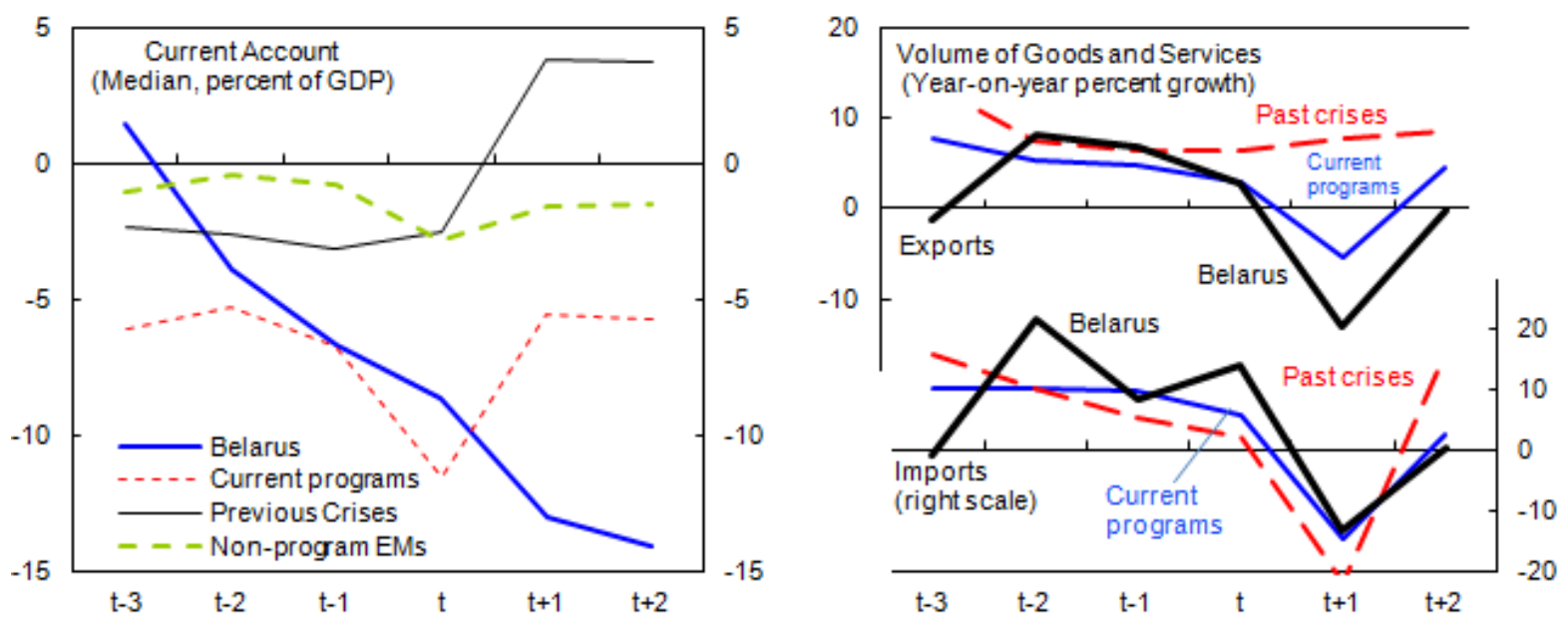

Source: IMF staff estimates and calculations.

\footnotetext{
${ }^{6}$ Countries included for comparison are countries with non-concessional Fund programs that qualified for exceptional access at the time of the approval.
} 
40. Although the external accounts turned out very differently than expected, modest augmentation of Fund financing proved sufficient. Rollover assumptions for short-term external credit to the economy at about 60-70 percent were appropriate for the circumstances. At the same time, the expected current account adjustment under the program was also realistic ex ante, given the experience of other countries (median current account adjustment in the current programs was 6 percentage points of GDP). In the event, the current account widened rather than narrowing, but this was broadly offset by better-thanexpected financial account outcomes.

41. As for phasing, the program was less frontloaded than others, reflecting the current account focus of the crisis. In contrast to other program countries, which underwent capital account crises, Belarus's problem was largely trade related (terms-of-trade and partner country demand shocks). The reversal of capital inflows that characterizes a typical capital account crisis played a role, but did not predominate (see below). Some frontloaded of program financing was, however, provided to help boost confidence, particularly following the large step devaluation at the inception of the program.

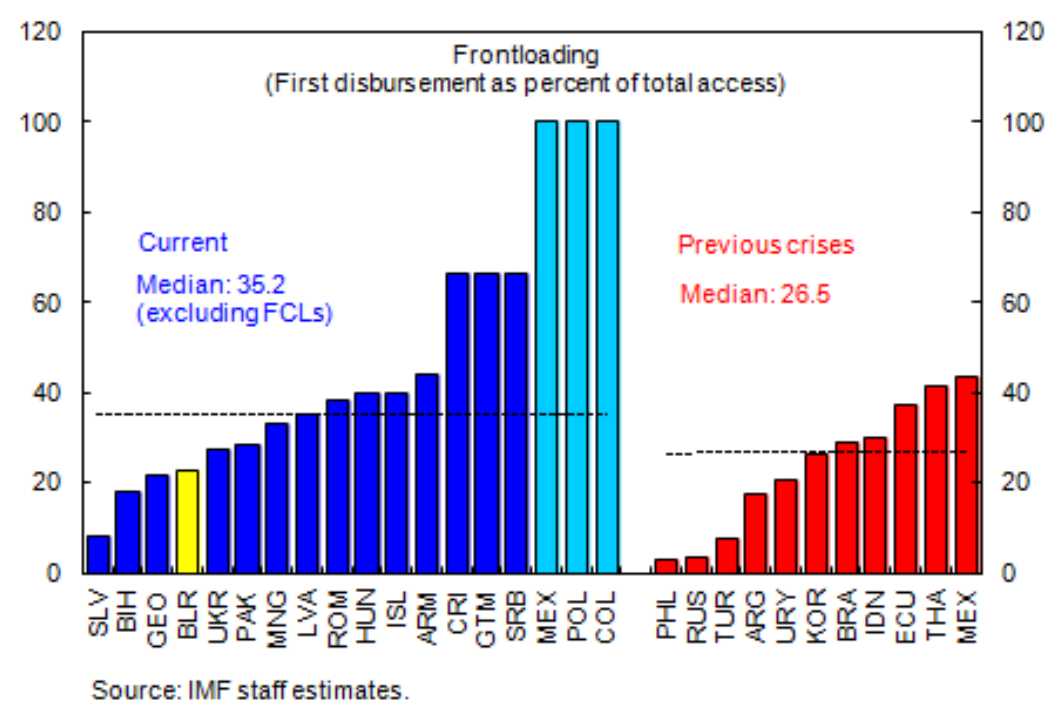

\section{Exceptional Access Procedures}

42. In line with the procedures for exceptional access, Belarus's original and augmentation requests were judged in light of the four criteria. ${ }^{7}$ Overall, the exceptional access criteria ${ }^{8}$ were adequately assessed in the note attached to the staff report:

\footnotetext{
${ }^{7}$ Exceptional access was granted under the exceptional circumstances clause.

${ }^{8}$ For the original request, approved prior to March 24, 2009, the EPE assessments was undertaken against thenexisting criteria upon which the programs were approved. The augmentation was assessed against current exceptional access criteria.
} 
- The original paper recognized that the first criterion — exceptional balance of payments pressure in the capital account resulting in a need for Fund financing that cannot be met within normal limits-played a role (lower bank credit rollover and weaker FDI) but was not the major issue. Instead the paper indicated clearly that Belarus was suffering large current account pressures due to adverse terms-of-trade developments and a considerable decline in demand for its exports. In the augmentation request, it was noted that current account pressures were in line with the new exceptional access criteria and that a significant decline in capital inflows was also expected.

- The second criterion - rigorous and systematic analysis indicating that there is high probability that debt will remain sustainable — was adequately assessed. The reports argued that both external and public debt levels were low, with standard bound tests indicating that Belarus's public debt situation remained manageable even under severe shocks.

- $\quad$ As for the third criterion — good prospects of regaining market access within the time that Fund resources would be outstanding - the reports recognized that Belarus did not have access to international financial markets even before the crisis, but argued that successful implementation of the program could allow Belarus to gain some access to private capital markets by the time repurchase obligations to the Fund became due. Belarus managed recently to launch a maiden Eurobond issue.

- The papers argued that the fourth criterion - policy program provides a reasonably strong prospect of success, including the institutional and political capacity to deliver the necessary adjustment - was met as the program contained policies that suggested strong prospects for success, including in the form of strong prior actions. The original paper did, recognize, however, that strict implementation of the program was essential and that even small deviations from proposed policies would greatly increase risks.

43. As called for under the policy, early Board involvement took place in the lead up to the request for the SBA. Two briefings on the program request and negotiation took place, along with two meetings on the need for exceptional access. The Board was provided with additional information, including a report assessing the risks to the Fund and the Fund's liquidity position. The staff reports and the authorities' Letter of Intent and Memorandum of Economic and Financial Policies have been published.

\section{Assessment of Program Performance}

\section{After analyzing program design in depth, we now turn our attention to overall} program performance, the second EPE objective. This comprises two key aspects: (i)outcomes versus projections, and (ii) outcomes compared with other cases.

45. Program outcomes relative to original targets were mixed, which is not surprising given the large shocks experienced over the program period. 
- $\quad$ All but one quantitative performance criteria were met. The exception was the net international reserves PC for March-2009 when the pressure was highest on the rubel. Performance relative to the program's structural conditions, as discussed earlier, was generally strong.

- At some points non-conventional actions helped the authorities to meet the NIR targets. For example, the NIR and NDA PCs for end-December 2009 would not have been met without a transaction to lengthen the maturity of foreign government deposits to just over one year so that they were not counted as foreign liabilities under the program definition of NIR. An alternative approach might have focused on period average, rather than end-point, monetary PCs.

- The key differences between program macroeconomic objectives and outcomes lie on the external side (Figure 1). Although growth and inflation outturns were not that different than originally expected, external current account outcomes were an order of magnitude worse, reflecting both import (LGP-fueled imports and higher import costs following the reduction in Russia subsidies) and export (terms of trade, partner country demand) developments (Box 3). Since these were largely offset by improved capital account inflows, gross reserves were largely in line with projections, although external debt turned out higher than envisaged.

46. Performance relative to other program countries was similarly mixed.

Specifically, although growth was better than other cases on average, the current account deficit was wider and the external debt increase sharper (Figure 2).

47. Post-program performance reinforces the importance of ownership, including at the highest levels. Although the authorities have pressed ahead with structural reforms in the area of privatization in the wake of the program, fiscal policies have been eased somewhat, LGP continues apace, and the external current account deficit remains high (partly as a result of the new oil import agreement with Russia) and reserves low. This leaves Belarus with vulnerabilities, mainly on the external side, that still need to be addressed in the wake of the program.

48. Finally, given the importance of ownership, explicit endorsement of the goals of any future program should be secured at the very highest levels. Ideally, this should also be combined with an approach that sets critical measures as prior actions. 


\section{Box 3. How did the Program Deal with Risks?}

The program acknowledged at the outset the considerable downside risks facing Belarus. These included a disorderly exit from the currency basket corridor, a sharper slowdown in Belarus's major trading partners, a sharp Russian ruble depreciation, and problems with market access due to deleveraging in the financial markets.

The response was to rely on strong program implementation, program buffers, and a pledge by the authorities to take additional measures as needed. As discussed, program implementation was generally strong, including through the implementation of critical prior actions (devaluation, restricting government deposit transfers to commercial banks, and wage and budget targets). The authorities also responded by taking additional fiscal measures as needed. Excessive LGP credit expansion was the exception. In terms of buffers, the program had some built-in flexibility to deal with risks, including a more flexible exchange rate regime, and automatic adjustors to address excesses or shortfalls in external financing and privatization proceeds. The program also relied on frequent (quarterly) reviews to help address program shocks in a timely manner.

Despite generally good program implementation and in-built flexibility, additional measures were needed during the program. These included additional depreciation, band widening, and LGP constraints.

\section{What are the key lessons?}

- A tighter program (mainly on LGP provision) may have helped render the program more robust, but the extent to which this was achievable is debatable given the authorities' commitment to directed lending.

- $\quad$ Additional measures taken during program reviews helped mitigate the impact of shocks. Program reviews appear to have been an effective, albeit time-consuming, tool to revisit the balance between policy adjustment and program financing and adopt targeted measures in response to the shifting profile of risks. 
Belarus: Quantitative and Continuous Performance Criteria under SBA approved on January 12, 2009 1/

\begin{tabular}{|c|c|c|c|c|c|c|c|c|c|c|c|c|c|c|c|}
\hline & \multicolumn{3}{|c|}{ March, 2009} & \multicolumn{3}{|c|}{ June, 2009} & \multicolumn{3}{|c|}{ Sep., 2009} & \multicolumn{3}{|c|}{ Dec., 2009} & \multicolumn{3}{|c|}{ Mar., 2010} \\
\hline & $\begin{array}{r}\text { Program } \\
\text { PC }\end{array}$ & $\begin{array}{r}\text { Adjusted } \\
\text { PC }\end{array}$ & Actual & $\begin{array}{r}\text { Revised } \\
\text { PC }\end{array}$ & $\begin{array}{r}\text { Adjusted } \\
\text { PC }\end{array}$ & Actual & PC & $\begin{array}{r}\text { Adjusted } \\
\text { PC }\end{array}$ & Actual & $\begin{array}{r}\text { Revised } \\
\text { PC }\end{array}$ & $\begin{array}{r}\text { Adjusted } \\
\text { PC }\end{array}$ & Actual & $\begin{array}{c}\text { Modified } \\
\text { indicative } \\
\text { target }\end{array}$ & $\begin{array}{c}\text { Adjusted } \\
\text { indicative } \\
\text { target }\end{array}$ & Actual \\
\hline \multicolumn{16}{|l|}{ 1. Performance criteria } \\
\hline Ceiling on the cash deficit of the general government (billions of Belarusian rubels, -implies a surplus) $2 / 3 /$ & -400 & $\ldots$ & -708 & -700 & 1,111 & 961 & $-1,000$ & 254 & 158 & 0 & 1,605 & 1,320 & 700 & 700 & 476 \\
\hline Floor on net international reserves of the NBRB (millions of U.S. dollars) $4 /$ & -510 & $-1,010$ & $-1,231$ & $-1,819$ & $-2,321$ & $-2,285$ & $-1,938$ & $-2,066$ & $-1,916$ & $-1,539$ & $-1,657$ & $-1,615$ & $-1,275$ & $-1,486$ & $-2,476$ \\
\hline Ceiling on net domestic assets of the NBRB (billions of Belarusian rubels) $4 /$ & 74 & 1,152 & 915 & 2,603 & 3,685 & 3,330 & 3,190 & 3,467 & 2,972 & 2,644 & 2,901 & 2,663 & 1,817 & 2,271 & 4,426 \\
\hline
\end{tabular}

Sources: Belarusian authorities; and IMF staff estimates and projections.

1/ Definitions are specified in the Technical Memorandum of Understanding (TMU) for the third review (IMF Country Report No. 10/31, pp. 44-54).

2/ Cumulative flows from the beginning of each calendar year.

$3 /$ The performance criterion on the ceiling of the government deficit was adjusted for projects initiated before the program up to the limit of $\$ 353$ million, for the cash deficit of local governments up to a limit of 1.4 trillion rubels, and the deviations in the

external budgot and project support chlated alter goverogram. The nonprogran

$4 /$ Cumulative flows from end-November 2008 at program exchange rates. 
Figure 1. Belarus: Program Projections and Outcomes (Percent, unless otherwise indicated)
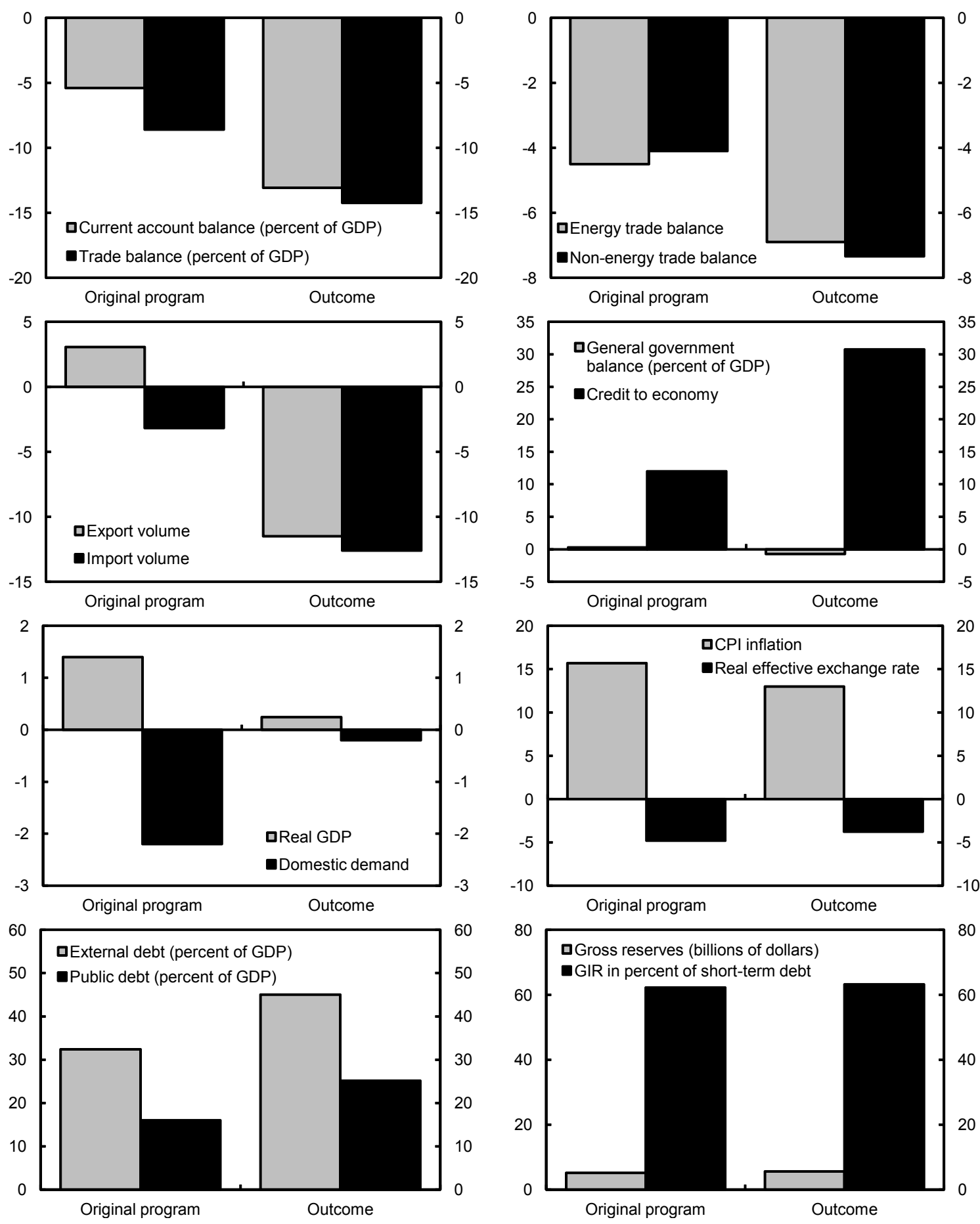

Source: IMF staff estimates and projections. 
Figure 2. Belarus: Comparison of Macroeconomic Performance with Other Program Countries (Median) 1/
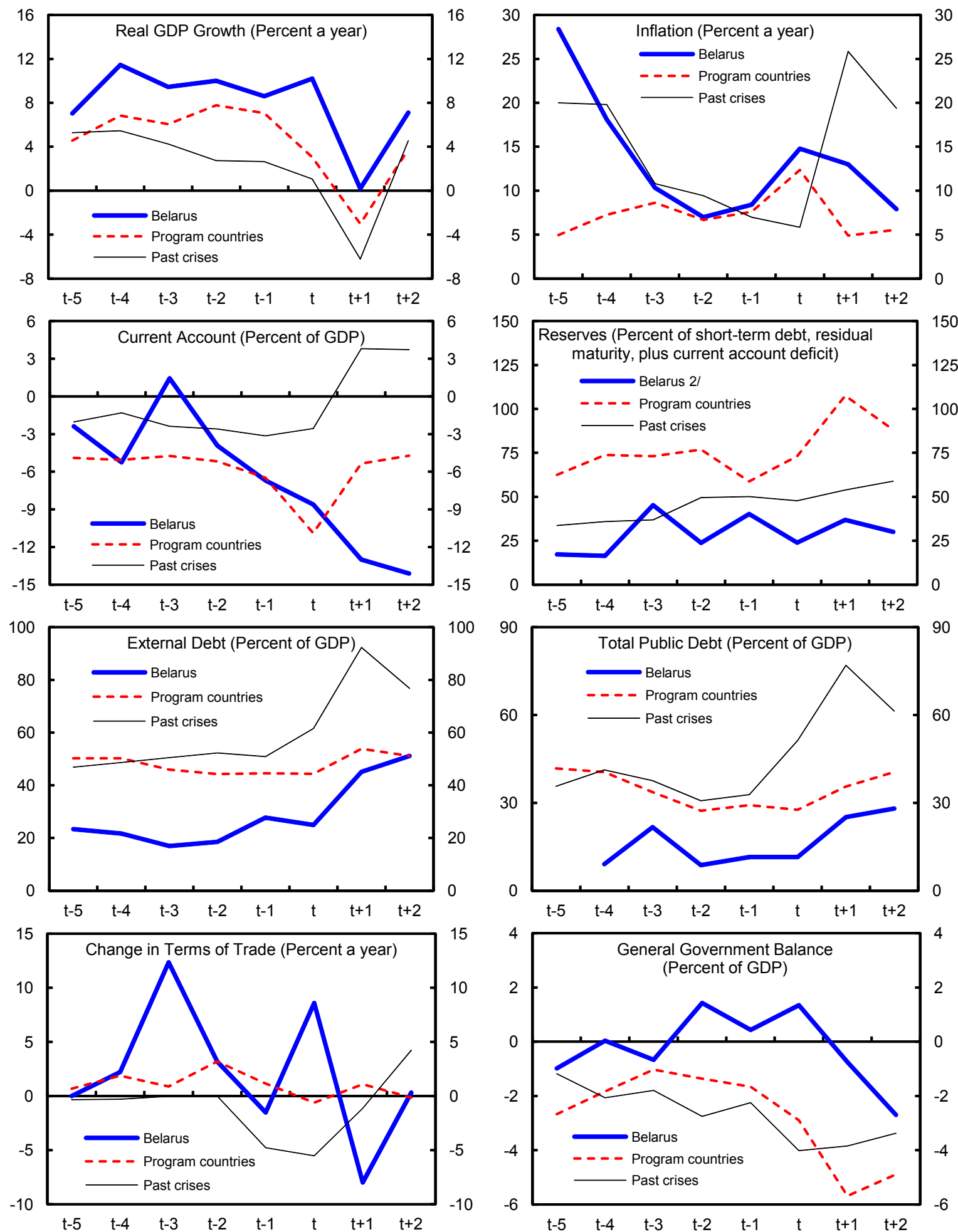

Sources: IMF, World Economic Outlook; and IMF staff calculations

$1 / t$ is 2008 for current program countries. Data for $t+2$ reflects October 2010 WEO projection.

2/ Percent of short-term debt, original maturity, plus current account deficit. 
Table 1. Belarus: Selected Economic Indicators, 2007-10

\begin{tabular}{|c|c|c|c|c|c|c|c|c|c|}
\hline & \multirow[t]{2}{*}{2007} & \multirow[t]{2}{*}{2008} & \multicolumn{6}{|c|}{2009} & \multirow{2}{*}{$\begin{array}{l}2010 \\
\text { Proj. }\end{array}$} \\
\hline & & & Prog. & 1st rev. & 2nd rev. & $3 d$ rev. & 4th rev. & Actual & \\
\hline & \multicolumn{9}{|c|}{ (Annual percentage change, unless otherwise specified) } \\
\hline \multicolumn{10}{|l|}{ National accounts } \\
\hline Real GDP & 8.6 & 10.2 & 1.4 & -3.3 & -1.2 & -0.3 & 0.2 & 0.2 & 7.1 \\
\hline Total domestic demand & 11.9 & 17.8 & -2.2 & -4.7 & -1.2 & -0.8 & 1.0 & -0.2 & 6.5 \\
\hline Consumption & 9.7 & 12.5 & -0.7 & -3.5 & -5.3 & -4.1 & -0.2 & 0.0 & 6.4 \\
\hline Nongovernment & 13.4 & 16.3 & -1.0 & -2.0 & -5.3 & -3.8 & 0.5 & 0.4 & 7.5 \\
\hline Government & -0.5 & 0.3 & 0.0 & -9.0 & -5.0 & -5.0 & -2.8 & -1.4 & 2.5 \\
\hline Investment & 16.4 & 28.2 & -4.9 & -7.0 & 6.0 & 5.1 & 3.2 & -0.6 & 6.7 \\
\hline Of which: fixed & 16.4 & 23.8 & -5.0 & -8.0 & 6.5 & 5.5 & 8.6 & 7.6 & 8.5 \\
\hline Net exports $1 /$ & -1.5 & -9.4 & 3.9 & 2.2 & 0.3 & 0.6 & -0.2 & 1.5 & -0.2 \\
\hline \multicolumn{10}{|l|}{ Consumer prices } \\
\hline End of period & 12.1 & 13.3 & 11.5 & 11.0 & 11.0 & 10.5 & 10.1 & 10.1 & 11.0 \\
\hline Average & 8.4 & 14.8 & 15.7 & 13.5 & 13.0 & 13.0 & 13.0 & 13.0 & 7.9 \\
\hline \multicolumn{10}{|l|}{ Monetary accounts } \\
\hline Reserve money & 38.4 & 11.7 & 14.5 & -9.0 & -8.7 & -9.2 & -11.3 & -11.3 & 113.6 \\
\hline $\begin{array}{l}\text { Rubel broad money } \\
\text { Growth of credit to the economy at program }\end{array}$ & 35.0 & 22.5 & 16.9 & -3.2 & -7.5 & -6.4 & 1.0 & 1.0 & 28.9 \\
\hline \multirow[t]{2}{*}{ exchange rates $2 /$} & $\ldots$ & 53.6 & 11.7 & 11.0 & 17.1 & 24.2 & 30.7 & 30.7 & 35.4 \\
\hline & \multicolumn{9}{|c|}{ (Percent of GDP) } \\
\hline \multicolumn{10}{|l|}{ External debt and balance of payments } \\
\hline Current account & -6.7 & -8.6 & -5.4 & -7.8 & -9.6 & -11.0 & -12.9 & -13.0 & -14.1 \\
\hline Trade balance & -8.9 & -10.3 & -8.6 & -10.1 & -11.9 & -12.0 & -14.2 & -14.2 & -15.7 \\
\hline Exports of goods & 53.8 & 54.0 & 52.5 & 51.3 & 47.4 & 44.3 & 43.6 & 43.6 & 45.4 \\
\hline Imports of goods & -62.7 & -64.3 & -61.2 & -61.4 & -59.2 & -56.3 & -57.8 & -57.8 & -61.1 \\
\hline Gross external debt & 27.7 & 25.0 & 32.4 & 38.8 & 41.7 & 42.8 & 44.4 & 45.1 & 51.2 \\
\hline Public 3/ & 6.5 & 6.8 & 11.8 & 17.0 & 18.9 & 17.9 & 18.2 & 18.2 & 21.6 \\
\hline Private (mostly state-owned-enterprises) & 21.2 & 18.1 & 20.6 & 21.7 & 22.9 & 24.9 & 26.2 & 26.9 & 29.7 \\
\hline \multicolumn{10}{|l|}{ Savings and investment } \\
\hline Gross domestic investment & 34.1 & 37.6 & 32.9 & 34.2 & 37.9 & 38.0 & 36.6 & 38.3 & 40.2 \\
\hline Government & 8.5 & 10.0 & 8.0 & 6.2 & 7.5 & 7.3 & 8.2 & 8.2 & 7.0 \\
\hline Nongovernment & 25.6 & 27.6 & 24.9 & 28.0 & 30.5 & 30.7 & 28.4 & 30.1 & 33.3 \\
\hline National saving & 27.4 & 29.0 & 27.5 & 26.4 & 28.3 & 27.0 & 23.7 & 25.3 & 26.1 \\
\hline Government & 8.9 & 11.3 & 8.3 & 6.2 & 5.7 & 6.2 & 7.4 & 7.4 & 4.3 \\
\hline Nongovernment & 18.5 & 17.7 & 19.2 & 20.2 & 22.6 & 20.8 & 16.3 & 17.8 & 21.9 \\
\hline \multicolumn{10}{|l|}{ Public sector finance } \\
\hline Republican and local government balance & -0.6 & 0.0 & 0.0 & 0.0 & -1.7 & -1.9 & -1.8 & -1.8 & -3.3 \\
\hline General government balance & 0.4 & 1.3 & 0.3 & 0.0 & -1.7 & -1.1 & -0.7 & -0.7 & -2.7 \\
\hline Revenue & 49.5 & 50.6 & 48.9 & 43.2 & 43.5 & 44.2 & 45.9 & 45.9 & 41.1 \\
\hline Expenditure & 49.0 & 49.2 & 48.6 & 43.2 & 45.2 & 45.3 & 46.6 & 46.6 & 43.8 \\
\hline \multicolumn{10}{|l|}{ Of which: } \\
\hline Wages & 8.0 & 6.6 & 6.4 & 6.5 & 6.6 & 6.7 & 6.8 & 6.8 & 7.4 \\
\hline Subsidies and transfers & 10.5 & 11.5 & 9.6 & 10.0 & 10.9 & 11.1 & 11.7 & 11.7 & 9.2 \\
\hline \multirow[t]{2}{*}{ Investment } & 8.5 & 10.0 & 8.0 & 6.2 & 7.5 & 7.3 & 8.2 & 8.2 & 7.0 \\
\hline & \multicolumn{9}{|c|}{ (Annual percentage change, unless indicated otherwise) } \\
\hline \multicolumn{10}{|l|}{ Memorandum items: } \\
\hline Nominal GDP (trillions of rubels) & 97.2 & 129.8 & 151.6 & 145.2 & 140.0 & 138.4 & 136.8 & 136.8 & 160.4 \\
\hline Terms of trade & -1.5 & 8.6 & -3.5 & -1.1 & 0.6 & -7.2 & -8.3 & -8.0 & 0.3 \\
\hline Real effective exchange rate & -3.9 & 1.6 & -4.8 & 0.3 & -1.9 & -2.9 & -3.8 & -4.5 & -5.0 \\
\hline Official reserves (billions of U.S. dollars) & 4.2 & 3.1 & 5.2 & 5.2 & 5.8 & 5.6 & 5.7 & 5.7 & 5.5 \\
\hline Months of imports of goods and services & 1.2 & 1.2 & 1.7 & 1.9 & 2.2 & 2.3 & 2.2 & 1.9 & 1.6 \\
\hline Percent of short-term debt & 56.8 & 40.4 & 62.2 & 74.5 & 81.4 & 68.3 & 61.8 & 63.2 & 51.4 \\
\hline
\end{tabular}

Sources: Belarusian authorities; and IMF staff estimates.

1/ Contribution to growth.

2/ Growth rate for 2010 is based on end-September, 2010 exchange rates.

$3 /$ Gross consolidated debt of the public sector (central bank and general government debt including publicly guaranteed debt). 


\section{ANNEX \\ Comments on the International Monetary Fund Report "Retrospective Evaluation of 2009 Stand-By Credit Arrangements with Exceptional Access"}

\section{General Comments}

On the whole, the IMF staff report "Retrospective Evaluation of 2009 Stand-By Credit Arrangements with Exceptional Access" (henceforth - report) appears sufficiently balanced and objective, and generally reflects a positive evaluation of the stand-by program in the Republic of Belarus. Only insufficient limitation of lending under government programs is noted in the report as the single essential shortcoming of the program.

The stand-by program was entered into in a difficult moment of the global financial and economic crisis, and in the presence of considerable uncertainty on the international financial and commercial markets, and in the global economy as a whole.

Prior to 2007, the economy of the Republic of Belarus developed at a high rate and with adequate balance. Starting in 2007, however, as a result of an external shock taking the form of rapid growth of prices of energy resources, the negative influence on the economy of the Republic grew constantly. The prices of imported natural gas in 2008 were 2.7 times the prices of 2006, while the prices of imported oil grew by 1.6 times, which led to worsening of the energy balance of the Republic of Belarus from a figure of plus USD 0.1 billion in 2006 to minus USD 2 billion based on results for 2008 .

\section{Owing to such a strong, persistent external shock the Republic of Belarus was} unable to react quickly and fully to it, and restructure its economy: lower its imports-, energy-, and materials-intensiveness, and organize the flow of labor, material, and financial resources over to more-efficient and less-costly industries. Although rather visible progress has already been made in modernization and restructuring, it is still insufficient for full adaptation to the shock.

In late 2008 and in 2009 the external shock caused by growth of the prices of energy resources was compounded by the shock of the international financial and economic crisis, which expressed itself first and foremost as a decrease in external demand and reduction of the possibilities for influx of foreign capital into the country.

As a result of rather severe regulatory measures taken by the government and the National Bank, especially in the monetary and fiscal sphere, which were designed with, among other things, the assistance of the IMF, the Republic of Belarus managed to make it through this difficult period honorably enough. GDP dynamics, the public's monetary income, and investment activity were kept positive as a foundation for future economic growth. 
For Your Information: Among all countries of the European region, economic growth was recorded in 2009 only in Poland, Israel, Albania, and Kosovo. In contrast to these and other states that were impacted only by the shock connected with the global crisis (limited demand for exports and outflow or decrease of inflow of capital), the Republic of Belarus suffered the effects of two shocks.

In such conditions, in addition to supporting economic growth and avoiding social tensions, we were able to maintain macroeconomic and financial stability. The budget deficit was not large, and although government and external debt did increase, it remained on the safe level and the banking sector operated without trouble.

Were it not for the shock caused by growth of energy prices, for practical purposes the Republic of Belarus would not have been impacted by the global financial crisis. This is connected first and foremost with the small role played by Belarus in the international financial market, and its low dependence upon international capital flows.

As for support to banks (nonstandard refinancing) and a relatively high rate of lending to government programs, it should be noted that practically all countries, including developed ones (USA, countries of the European Union), resorted to this instrument in the face of the crisis, and to a rather sizable extent at that.

These instruments were applied with the purpose of supporting business. The one thing that distinguished the Republic of Belarus was that while most countries, including developed countries, did so through budget mechanisms that increased the state budget deficit, the Republic of Belarus provided such support through quasi-budget mechanisms through support to banks and further lending to the economy while keeping the budget deficit practically at zero.

For Your Information: The budget deficit in the Republic of Belarus was practically the lowest in the world, and the lowest in the European region (except for Norway and Switzerland, where a surplus was observed) - 0.7 percent of GDP. As an example, in the European region the average budget deficit in 2009 was $6.2 \%$ of GDP, with the deficit exceeding $10 \%$ of GDP in Greece, Spain, Ireland, Iceland, and Great Britain.

Thus, all things considered support to the economy in the Republic of Belarus was even lower than in other countries, and this was in the face of two shocks.

Regarding the housing construction program, we should note that by as early as 2011 the pace of housing construction slowed significantly. Thus, while in 2006-2010 the average annual increase in placement of housing in service was about $113 \%$, growth of this indicator is anticipated in 2011 at just $107.8 \%$.

For Your Information: An analysis of the influence of lending to housing construction on the external economic equilibrium needs to also consider that $95 \%$ is for 
purchases of Belarusian materials, and only 5\% is for purchases of imported materials. Correspondingly, the overall savings from the decrease in housing construction in 2009 was only USD 300-350 million.

Such a decrease could have had extremely negative social and economic consequences.

Besides that, lending to housing construction significantly stimulates the public to invest its uncommitted monetary resources into construction, as an alternative to buying foreign exchange (which is especially important in a time of high expectations of devaluation). Thus, according to rough calculations the public invested the equivalent of more than USD 1.2 billion of its own resources into housing construction in 2009, or 5\% more than in 2008, which was a relatively good year, and use of this investment vehicle for the public's monetary resources increased to 3.9\%, as opposed to 3.3\% in 2008. This could be viewed as one of the stabilizing factors and stimulants of economic growth.

Thus, the situation in which the economy of the Republic of Belarus found itself in recent years was the result of an external persistent energy shock intensified by the negative influence of the global financial and economic crisis.

In our view, further measures to support macroeconomic equilibrium and to adapt the Belarusian economy to external shocks lie first and foremost not in the area of monetary policy but in the area of deep reform of the economy. Only restructuring of the Belarusian economy will make it possible to increase its effectiveness and competitiveness, and thus lay the foundation for sustained development over the long term. At the same time, this highly difficult task will need considerable time, as well as investment of great amounts of financial resources.

It needs to be noted that the time period for implementation of the stand-by program and the volume of its financing in the Republic of Belarus did not allow us to fully surmount the structural vulnerability of the Belarusian economy.

In order to surmount the problems fully and finally in a situation analogous to that prevailing in the Belarusian economy due to the impacts of external shocks, we need a major, appropriately funded program running 3-4 years. The main emphasis in it should be made not on measures of macroeconomic adjustment, but on economic restructuring. As we see it, this will go a long way to facilitate the country's return to a trajectory of sustained, long-term economic growth and reduction of its economy's vulnerability to shocks in the future.

\section{Some Particular Points}

Some of the premises set forth in the IMF report do not fully reflect the situation prevailing in the Republic of Belarus, both in the pre-crisis period and in the time of the program's action. This pertains in particular to the following points. 


\section{Concerning growth of the vulnerability of the economy in the pre-crisis level}

From the IMF report: "Although in the years preceding the crisis economic indicators were generally high, the global upheavals revealed profound vulnerabilities in the economy, including an inflated foreign exchange rate, a large deficit in the current external operations account, a dependence upon Russian subsidies on energy resources, and reserves so low to be risky.

In our view, the greatest weaknesses in the Belarusian economy are not these factors but its insufficient effectiveness, expressed first and foremost as low competitiveness on external markets, significant imports-, energy-, and materials-intensiveness, and insufficiently effective investments. These are precisely the indicators that determine the slow pace of adaptation of the economy of the Republic of Belarus to external shocks (including due to energy prices) and to the influence of the global financial crisis.

\section{The exchange rate of the Belarusian ruble exhibited a tendency to fall in both} nominal and real terms over the course of a number of years preceding the global financial and economic crisis. During that period, moreover, it remained close to its equilibrium value, it was in harmony with the principal economic indicators, and it did not have a negative influence on the stability of the balance of payments and on the status of international reserve assets.

In the second half of 2008, the increase in the real exchange rate of the rubel occurred on the backdrop of a fast drop in the exchange rates of the currencies of countries serving as the main trading partners, and it was caused by the obligation of monetary regulators to assure that the exchange rate of the domestic currency was pegged to the U.S. dollar within the framework of the exchange rate regime prevailing at that time and the parameters of monetary policy approved by the president of the Republic of Belarus for 2008.

At the same time, analysis of the dynamics of the real exchange rate of the Belarusian ruble based on statistical methods shows that the real exchange rate is generally consistent today with its historical trajectory. From December 2000 to June 2008 the real effective exchange rate of the rubel weakened by $19.1 \%$, to include a $29.1 \%$ drop relative to the ruble.

The negative balance of the current account had a tendency to increase owing to continual worsening of the conditions of external trade connected with change in prices and in the terms for deliveries of energy goods. At the same time, it did not present a threat from the standpoint of maintaining external stability (the relative level of external debt and its structure remained stable). Besides that, the size of monetary flows in the capital and financial operations account did not carry significant risks to the stability of external positions.

The inflow into the capital and financial operations account remained stable up to the start of the global financial and economic crisis (August 2008). Thus, the inflow of capital 
into the financial account was USD 5.2 billion in 2007 and USD 1.7 billion in January-July 2008.

Gold and foreign exchange reserves of the Republic of Belarus increased from January 1, 2007 to August 1, 2008 by USD 3.2 billion, or by a factor of 3.3, coming to USD 4.6 billion. In January-July 2008 they increased by almost USD 0.5 billion.

The gold and foreign exchange reserves indicator expressed in months of imports was low owing to growth of the both exports and imports in value terms, which was brought about in turn by growth of world prices. While during 2007 this indicator increased to 1.65 months of imports from 0.7, in January-July 2008 it shrank to 1.4 months of imports.

\section{Concerning worsening of the balance of external trade in 2008-2009.}

From the IMF report: "This is one of the few anti-crisis programs under which the current account deficit increased."

One of the key causes of growth of the current account deficit in the Republic of Belarus in recent years was the constant increase in fuel prices. And it would be impossible, in our view, to reduce the impact of this shock in a short period of time without restructuring and modernizing the economy. The measures undertaken under the program, meantime, did have a positive effect.

Over the course of 2007-2010 we observed significant worsening of the balance of external trade, which has its origins first and foremost in worsening of the conditions of trade in energy resources, and development of the global economic crisis.

The balance of trade of the Republic of Belarus worsened in 2009 compared to 2006 by USD macro 4.6 billion, and the decrease in the trade balance in January-September 2010 compared to the same period of 2009 was USD 0.8 billion. The main factor behind this decrease was worsening of the balance of external trade in energy goods by USD 3.5 billion and USD 1.3 billion respectively.

The balance of external trade in nonenergy goods, less potassium fertilizers, changed insignificantly in 2007 compared to 2006, and when we account for growth of the economy it improved from $-9.5 \%$ to $-8.2 \%$ of GDP. At the same time, in the face of development of the global economic crisis and a decrease in external demand for Belarusian products, worsening of the balance of external trade in nonenergy goods less potassium fertilizers came to USD 3.8 billion in 2008 compared to 2007, or 4.2 percentage points of GDP.

Measures undertaken under the stand-by program made it possible to significantly lower the deficit in external trade in nonenergy goods.

Significant improvement of the balance of external trade in nonenergy goods less potassium fertilizers was noted in 2009 - by USD 2.6 billion, or by 2.3 percentage points of 
GDP. In January-September 2010 the balance of trade less energy goods and potassium fertilizers improved somewhat compared to the same period of 2009 - to -9.4 from $-9.5 \%$ of GDP.

It may be noted that on the whole, notwithstanding the influences of the global economic crisis the balance of external trade in nonenergy goods less potassium fertilizers is now close to the 2006 level (in relative terms) as a result of the measures undertaken.

\begin{tabular}{|c|c|c|c|c|c|c|}
\hline & 2006 & 2007 & 2008 & 2009 & $\begin{array}{c}\text { January- } \\
\text { September } \\
2009\end{array}$ & $\begin{array}{c}\text { January- } \\
\text { September } \\
2010\end{array}$ \\
\hline \multicolumn{7}{|c|}{ Balance of trade, } \\
\hline USD million & -2383.7 & -4071.0 & -6166.4 & -6954.6 & -4802.4 & -5640.8 \\
\hline$\%$ of GDP & -6.4 & -9.0 & -10.1 & -14.2 & -13.4 & -14.4 \\
\hline \multicolumn{7}{|c|}{ 1. Balance of external trade in energy goods, } \\
\hline USD million & 131.7 & -1705.4 & -1999.9 & -3378.0 & -2427.6 & -3677.6 \\
\hline$\%$ of & 0.4 & -3.8 & -3.3 & -6.9 & -6.8 & -9.4 \\
\hline \multicolumn{7}{|c|}{ 2. Balance of external trade in potassium fertilizers, } \\
\hline USD million & 1014.6 & 1349.3 & 3362.8 & 1357.9 & 1019.7 & 1722.4 \\
\hline$\%$ of GDP & 2.7 & 3.0 & 5.5 & 2.8 & 2.9 & 4.4 \\
\hline \multicolumn{7}{|c|}{ 3. Balance of external trade in nonenergy goods less fertilizers } \\
\hline USD million & -3530.0 & -3714.9 & -7529.3 & -4934.5 & -3394.5 & -3685.5 \\
\hline$\%$ of GDP & -9.5 & -8.2 & -12.4 & -10.1 & -9.5 & -9.4 \\
\hline
\end{tabular}

\section{Concerning devaluation of the rubel in early 2009}

From the IMF report: "A larger devaluation in the initial phase would have helped Belarus deal with the subsequent abrupt drop in demand on the part of partner countries and with rapid devaluation of the Russian ruble."

As the influence of the global economic crisis intensified, from August 2008 we observed a strengthening of the real exchange rate of the rubel. As a result from July 2008 to December 2008 the real effective exchange rate of the rubel strengthened by $22.6 \%$.

In these conditions a one-time adjustment was made in the rubel in early 2009 (in particular, the exchange rate of the rubel against the U.S. dollar fell by 20\%) for the purposes of supporting the price competitiveness of domestic products. Besides that, during 2009 the rubel was allowed to weaken by $7.9 \%$ in the basket of foreign currencies.

Besides that, significant reliance was made in the IMF program on a macroeconomic adjustment policy aimed at managing demand, which went a long way to increase the importance of monetary and budget policy measures to correction of imbalances, compared to exchange rate policy measures. 
Also, the IMF memorandum itself (item 27) states that "the drop in external demand, particularly on the part of Russia, and worsening of trade conditions (significantly greater than in the cases of other countries with IMF programs) exceeded any increase in competitiveness as a result of devaluation." In our opinion this is inconsistent with the conclusion that there was a need for "greater devaluation in the initial phase."

It should be noted that the physical volume of non-energy exports began to increase in February 2009 in connection with resumption of demand and improvement of price conditions on the external markets. Thus, there was no need for an additional adjustment or for support of growing exports through exchange rate policy measures.

The decrease in the exchange rates of currencies in countries serving as trading partners (particularly the Russian Federation) that continued into January-February 2009 was compensated by employing a mechanism for pegging the exchange rate to the value of the basket of currencies, which was introduced at the year's start. Smoother adjustment of the exchange rate subsequently within the band did not have a significant impact on expectations of market participants, which facilitated favorable change in the cross exchange rates in the period of its performance.

Thus adjustment of the exchange rate at the commencement of the program, aimed at returning the exchange rate to a level close to equilibrium and its subsequent support within the bounds of a set band had a positive influence on reaching the goals of the program.

Today the real exchange rate of the rubel corresponds to the precrisis level: the decrease in the real effective exchange rate in September 2010 compared to July 2008 was $0.4 \%$, and compared to December 2007 it was $4.8 \%$. 